\title{
Mantle wedge oxidation due to sediment-infiltrated deserpentinisation
}

José Alberto Padrón-navarta ( $\sim$ alberto.padron@csic.es )

CSIC https://orcid.org/0000-0003-1005-0012

Vicente López Sánchez-Vizcaíno

Universidad de Jaén

Manuel Menzel

RWTH Aachen University

María Teresa Gómez-Pugnaire

Universidad de Granada

Carlos Garrido

CSIC

Article

Keywords:

Posted Date: December 9th, 2021

DOI: https://doi.org/10.21203/rs.3.rs-1050656/v1

License: (c) (1) This work is licensed under a Creative Commons Attribution 4.0 International License.

Read Full License 


\title{
Mantle wedge oxidation due to sediment-infiltrated deserpentinisation
}

\author{
Padrón-Navarta, J.A. ${ }^{1,2 *}$, López Sánchez-Vizcaíno, V. ${ }^{3}$, Manuel D. Menzel ${ }^{4}$, \\ María Teresa Gómez-Pugnaire ${ }^{1,5}$, Garrido, C.J. ${ }^{1}$ \\ ${ }^{1}$ Instituto Andaluz de Ciencias de la Tierra (IACT), CSIC-Universidad de Granada, Av. Palmeras 4, \\ 18100 Armilla, Granada, Spain. \\ ${ }^{2}$ Géosciences Montpellier, Université de Montpellier \& CNRS, F-34095 Montpellier cedex 5, France. \\ ${ }^{3}$ Dpto. de Geología (Unidad Asociada al IACT, CSIC-UGR), Universidad de Jaén, Escuela Politécnica \\ Superior, 23700 Linares, Jaén, Spain. \\ ${ }^{4}$ Institute of Tectonics and Geodynamics, RWTH Aachen University, Aachen, Germany. \\ ${ }^{5}$ Departamento de Mineralogía y Petrología, Universidad de Granada, 18002 Granada, Spain \\ *corresponding author (e-mail: alberto.padron@csic.es) \\ 2476 words/Summary (219 words)
}

The Earth's mantle is oxygen-breathing through the sink of oxidised tectonic plates at convergent margins $^{1,2}$. Ocean floor serpentinisation increases the bulk oxidation state of iron relative to dry oceanic mantle and results in a variable intake of other redox-sensitive elements such as sulphur ${ }^{2,3}$. The reversibility of seafloor oxidation in subduction zones during high-pressure dehydration of serpentinite ("deserpentinisation") at subarc depths and the capacity of the resulting fluids to oxidise the mantle source of arc basalts are highly contested ${ }^{4-15}$. Thermodynamic modelling ${ }^{8,10,15}$, experiments ${ }^{6,12,14}$, and metaperidotite study in exhumed highpressure terrains ${ }^{4,15,16}$ result in differing estimates of the redox state of deserpentinisation fluids, ranging from low to highly oxidant. Here we show that although intrinsic deserpentinisation fluids are highly oxidant, the infiltration of small fractions of external fluids equilibrated with metasedimentary rocks strongly modulates their redox state and oxidation-reduction capacity explaining the observed discrepancies in their redox state. Infiltration of fluids equilibrated with graphite-bearing sediments reduces the oxidant, intrinsic deserpentinisation fluids to oxygen fugacities similar to those observed in most graphite-furnace experiments and natural metaperidotites. However, infiltration of $\mathrm{CO}_{2}$-bearing fluids equilibrated with modern GLOSS generates sulphate-rich, highly oxidising deserpentinisation fluids. We show that such GLOSSinfiltrated deserpentinisation fluids can effectively oxidise the mantle wedge of cold to hot subduction zones potentially accounting for the presumed oxidised nature of the source of arc basalts. 


\section{Main (701 words)}

38 Interaction of seawater with the oceanic lithosphere results in alteration of the oceanic crust and hydration of mantle peridotite to serpentinite. Serpentinisation substantially increases the amount of water and the ferric iron over total iron ratio $\left(\mathrm{Fe}^{3+} / \Sigma \mathrm{Fe}\right)^{1,2,13,17,18}$ (Fig.1a; 0.4-1.0 with a median and an average value of 0.60 and $0.58, \mathrm{n}=601$ ) relative to that of the Depleted MORB Mantle (DMM, 0.015$0.04)^{19}$ (Fig. 1a), placing serpentinite among the most oxidised rocks of the altered oceanic lithosphere. Seafloor serpentinisation furthermore increases the content of redox-sensitive, multivalent elements, particularly sulphur, whose abundance varies by up to three orders of magnitude relative to DMM (Fig. $1 b)$, reflecting a large variability of oxygen fugacity $\left(f \mathrm{O}_{2}\right)$ and $\mathrm{S}$ intake processes.

Subduction of altered oceanic lithosphere triggers the high-pressure (high-P) dehydration of serpentinite at intermediate slab depths of subduction zones, a process usually referred to as deserpentinisation. Deserpentinisation is considered the main volatile source of arc magmatism and likely plays an important role in the recycling of redox-sensitive elements ${ }^{8,10,11,13}$ and the genesis of ore deposits $^{20}$. More controversial is the potential role of deserpentinisation aqueous fluids as oxidation agents of the mantle wedge source of arc magmatism, accounting for the more oxidised nature of arc basalts relative to MORBs ${ }^{5-8,12,14}$. While there is a consensus that water is mostly recycled back to the crust and atmosphere by deserpentinisation, the oxidation of seafloor serpentinites (Fig. 1a) is generally thought to be irreversible. While pure molecular species in aqueous fluids have a limited oxidising capacity $^{21}$, the redox capacity of deserpentinisation electrolytic fluids highly depends on their content in oxidised species bearing multivalent elements, particularly sulphur ${ }^{8,22,23}$. Sulphur species with a high oxidising capacity — such as sulphates - are thermodynamically predicted during deserpentinisation at $f \mathrm{O}_{2}$ near or above the hematite-magnetite oxygen buffer $^{8}$. Most deserpentinisation experiments, however, yield significantly lower $f_{2}{ }_{2}^{12,14}$. Rare metaperidotite formed by high-P dehydration of subducted serpentinite, now exhumed in metamorphic paleo-subduction terranes - Cerro del Almirez $(\mathrm{CdA})$ and Cima di Gagnone $(\mathrm{CdG})$ - also records lower oxidising conditions than those predicted by thermodynamic models ${ }^{4,15,24}$. High-P serpentinite (metaserpentinite) and metaperidotite from CdA have a rather narrow range of $\mathrm{Fe}^{3+} / \Sigma \mathrm{Fe}$ ratio $(0.60-0.64$, first and third quartile, $\mathrm{n}=27$ and $0.24-0.33, \mathrm{n}=21$ respectively, Fig. 1a) and magnetite content (3-4 wt.\%, n=19 vs. $0.3-1.1$ wt.\%, n=11, Supplementary Fig. 1), and the transition from metaserpentinite to metaperidotite results in a $40 \%$ decrease of its redox budget (from 0.7 to $0.4 \mathrm{~mol} / \mathrm{kg}$, Methods and Supplementary Fig. 4 and Table 1). The trend of decreasing $\mathrm{Fe}^{3+} / \Sigma \mathrm{Fe}$ content from metaserpentinite to metaperidotite in $\mathrm{CdA}$ has been ascribed to deserpentinisation ${ }^{16}$ suggesting the reversibility of seafloor serpentinisation oxidation during subduction (Fig. 1a), yet the ultimate cause for such reversal has not been provided. Alternatively, this trend is ascribed to different extents of oceanic serpentinisation of their protoliths ${ }^{4,15,24}$, implying the irreversibility of seafloor oxidation serpentinisation during subduction (Fig. 1a). This interpretation is however at odds with numerous textural and geochemical evidence for the provenance of CdA and CdG 


\begin{tabular}{|ll|}
\hline Serpentinites & Metaperidotite \\
High-pressure $(\mathrm{CdA})$ & $\bigcirc$ Metaperidotite $(\mathrm{CdA})$ \\
High-pressure Ca-poor (CdA) & $\bigcirc$ Transitional $(\mathrm{CdA})$ \\
Worldwide & $\bigcirc$ Metaperidotite $(\mathrm{CdG})$ \\
\hline
\end{tabular}

Thermodynamic modelling

$\ll$ Intrinsic deserpentinisation

<o- Graphite metapelite-infiltrated deserpentinisation
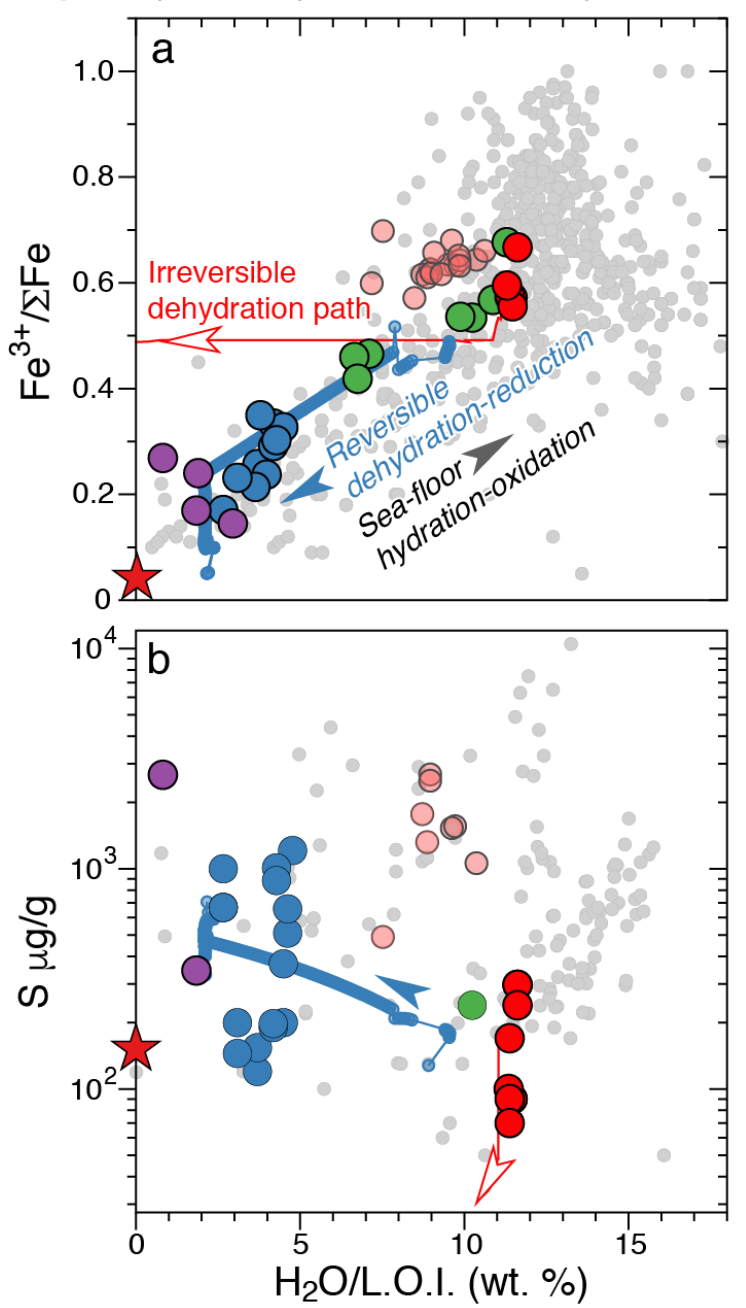

FIGURE 1a. The cycle of hydration-oxidation of mantle peridotite (serpentinites, grey arrow) at the Earth's ocean floor relative to the nominally anhydrous mantle (red star, Depleted MORB Mantle $^{9}$ ) and two possible deserpentinisation paths either reversing or preserving the oxidation set at the Earth's surface. The directions of the arrows for the thermodynamically modelled intrinsic and graphite metapelite-infiltrated deserpentinisation evolutions indicate the direction of $\mathrm{H}_{2} \mathrm{O}$ loss during subduction (depicted also in Fig. 2a). The only known rock samples from high-pressure terrains recording the deserpentinisation (metaperidotites from the Cerro del Almirez, CdA, and Cima di Gagnone, CdG, localities) match the reversible path requiring an external influx of reduced fluids during dehydration. Worldwide serpentinites also include partially serpentinized orogenic peridotites $\left(<9.0\right.$ wt.\% $\mathrm{H}_{2} \mathrm{O}$, see Methods). b. The observed increase in total $\mathrm{S}$ content in the CdA and $\mathrm{CdG}$ metaperidotites compared to serpentinites is also reproduced by the graphite metapeliteinfiltrated deserpentinisation model (blue arrow), in contrast to the intrinsic deserpentinisation model (red arrow). 
metaperidotites from highly serpentinised peridotite protoliths metasomatised by crustal fluids ${ }^{25-27}$. CdA metaperidotite is also characterised by a moderate increase in $\mathrm{S}$ relative to its putative Ca-poor serpentinite protolith - with a low S content $(<300 \mu \mathrm{g} / \mathrm{g})$ similar to DMM; an opposite trend to that predicted from thermodynamic modelling (Fig. 1b). Furthermore, subducted serpentinite has lower and narrower S contents than average oceanic serpentinite (Fig. 1b), thus limiting the capacity of deserpentinisation fluids to oxidise the mantle wedge. Thermodynamic modelling, experiments and natural samples thus provide seemingly contradictory views on the role of deserpentinisation fluids as potential agents for the oxidation of the mantle source of arc basalts.

The pervasiveness of subducted-sediment geochemical signatures is the hallmark of arc magmatism ${ }^{28}$, an attribute increasingly ascribed to the interaction of slab crustal lithologies with slab fluids sourced from deserpentinisation. There is also overwhelming geochemical evidence on the role of infiltration of fluids equilibrated with metasedimentary rocks in the genesis of natural serpentinitederived metaperidotite ${ }^{25-27,29-33}$. However, it has not yet been investigated how the interaction of sediment-derived fluids modify the $f \mathrm{O}_{2}$ and the cargo of multivalent elements in the deserpentinisation fluids, compared to those sourced from the intrinsic (i.e. without external fluid infiltration) deserpentinisation.

\section{Intrinsic deserpentinisation (396 words)}

92 Figure 2a shows the thermodynamic modelling of the intrinsic prograde evolution a serpentinite 93 subducted along the geothermal gradient of high-P metamorphic terrains. At constant bulk $\mathrm{O}_{2}$ (red arrows in Fig. 1a and 2a, Supplementary Fig. 2), this evolution implies a dramatic increase of the $\Delta \log _{10} f \mathrm{O}_{2}[\mathrm{FMQ}]^{7,10,34}$ from $+2.2\left(450{ }^{\circ} \mathrm{C}, 0.9 \mathrm{GPa}\right)$, where olivine is first produced, to $+4.6\left(660^{\circ} \mathrm{C}\right.$, $1.7 \mathrm{GPa}$ ), where antigorite serpentinite dehydrates to metaperidotite. The rise in $f \mathrm{O}_{2}$ is due to the formation of hematite after magnetite to maintain the bulk $\mathrm{Fe}^{3+} / \Sigma \mathrm{Fe}$ constant (Fig. 1a; red line) since the $\mathrm{X}_{\mathrm{Mg}}\left[\mathrm{Mg} /\left(\mathrm{Fe}^{2+}+\mathrm{Mg}\right)\right]$ of olivine and orthopyroxene reaction products is lower than that of reactant antigorite (Supplementary Fig. 3 and 4). In agreement with previous models for a similar $\Delta \log _{10} f \mathrm{O}_{2}[\mathrm{FMQ}]^{8}$, our model shows that $\mathrm{S}$ and $\mathrm{C}$ of serpentinite are fully dissolved in the deserpentinisation fluid, with $\mathrm{HSO}_{4}^{-}{ }_{\text {(aq) }}$ and, to a lesser extent, $\mathrm{SO}_{4}{ }^{2-}{ }_{(\mathrm{aq})}$ as the dominant sulphur species (Supplementary Table 2). 

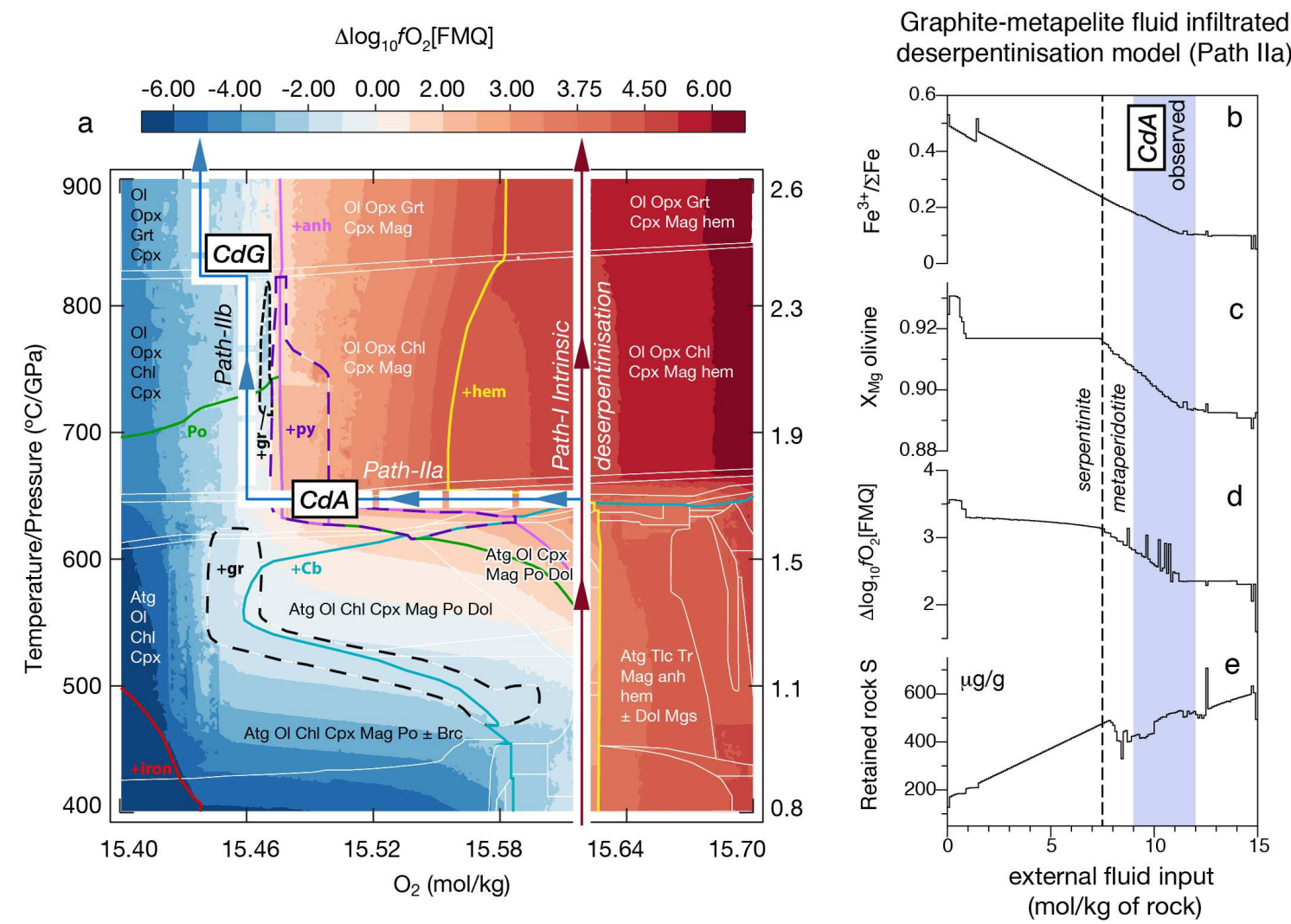

FIGURE 2a. Two potential evolutions of the oxygen fugacity $f \mathrm{O}_{2}$ for the subducting serpentinite slab (expressed as relative to the FMQ buffer; see Methods) for a geothermal gradient crossing the antigorite $\left(660^{\circ} \mathrm{C} / 1.7 \mathrm{GPa}\right)$ and chlorite dehydration $\left(820^{\circ} \mathrm{C} / 2.4 \mathrm{GPa}\right)$ as observed at $\mathrm{CdA}$ and $\mathrm{CdG}$ computed for a representative fully serpentinized peridotite containing $5 \mathrm{wt} . \%$ magnetite, $11.6 \mathrm{wt} . \%$ $\mathrm{H}_{2} \mathrm{O}, 170 \mathrm{ppm} \mathrm{S}$, and $200 \mathrm{ppm} \mathrm{C}$ (Figure 1 and Supplementary Table 1). Stability fields highlighting some key mineral assemblages are superimposed as thick lines (see Supplementary Figure 2). PathI ("Intrinsic deserpentinisation") corresponds to the conventional, closed system, prograde metamorphism where the rock imposes the $\mathrm{fO}_{2}$ and shows a dramatic increase in the $\Delta \log _{10} f \mathrm{O}_{2}[\mathrm{FMQ}]$ of up to +4.5 . Here we show that, alternatively, externally-derived fluid infiltration can induce complete antigorite dehydration at isobaric-isothermal conditions (horizontal Path-IIa, graphite-metapelite infiltrated deserpentinisation) with a decrease in the relative $f \mathrm{O}_{2}$ and in the redox budget if the infiltrating fluid is derived from a sediment (pyrite and graphite-bearing metapelite) with a high reducing capacity ${ }^{46}$. b-e. Isothermal and isobaric evolution $\left(650^{\circ} \mathrm{C} / 1.7 \mathrm{GPa}\right)$ along the computed, dehydration-driven infiltration path. The vertical dashed line marks the complete deserpentinization (for the Path-I intrinsic evolution see Supplementary Figure 4): b. Bulk-rock ferric to total iron content $\left(\mathrm{Fe}^{3+} / \Sigma \mathrm{Fe}\right)$. c. $\mathrm{X}_{\mathrm{Mg}}$ in olivine. d. $\Delta \log _{10} f \mathrm{O}_{2}[\mathrm{FMQ}]$. e. Total sulphur content retained in the reacting rock during the external infiltration. The blue-shaded range shows the extent of fluid-rock reaction necessary to induce full dehydration of serpentinite and reproduce the observed $\mathrm{Fe}^{3+} / \Sigma \mathrm{Fe}$ and $\mathrm{X}_{\mathrm{Mg}}$ in the CdA exhumed high-pressure terrain (metaperidotite). 

serpentinite and metaperidotite, such as the decrease of the bulk $\mathrm{Fe}^{3+} / \Sigma \mathrm{Fe}^{4,16,35}$ and the relative increase in $\mathrm{S}$ content in metaperidotite ${ }^{36}$ (Fig. 1); its magnetite content and lack of hematite, 16,24,35 (Supplementary Fig. 1); and the lower olivine $\mathrm{X}_{\mathrm{Mg}}{ }^{4,35}$ (Supplementary Fig. 4). Nor does it explain the substantially lower $\Delta \log _{10} f \mathrm{O}_{2}[\mathrm{FMQ}]\left(+2.1 \pm 0.3\right.$; at $\left.800{ }^{\circ} \mathrm{C}, 1 \mathrm{GPa}\right)$ found in most high-P serpentinite dehydration experiments ${ }^{12,14,37-39}$ that obtain olivine — coexisting with magnetite ${ }^{6,14,40}$ — with an $\mathrm{X}_{\mathrm{Mg}}$ that perfectly matches that of natural metaperidotite $e^{4,15,35,41}$. Although these lines of evidence might point to the non-validity of the thermodynamic model of intrinsic deserpentinisation, it is well known that the $f \mathrm{O}_{2}$ is externally buffered and biased towards lower $f \mathrm{O}_{2}$ in high-T, long-run, graphite-furnace experiments ${ }^{14}$. Interestingly, deserpentinisation experiments conceived to maintain high $\mathrm{fO}_{2}$ using $\mathrm{LaCrO}_{3}$ instead of graphite furnace ${ }^{6}$ obtain high $\mathrm{X}_{\mathrm{Mg}}$ olivine (0.94-0.97) coexisting with hematite and magnetite, and $\Delta \log _{10} f \mathrm{O}_{2}[\mathrm{FMQ}]$ ranging from +3.1 to +4.1 , in excellent agreement with our thermodynamic model predictions (Fig. 2 and Supplementary Fig. 4). As serendipitously attained in graphite-furnace experiments ${ }^{12,14,37-39}$, many natural metaperidotite features would be matched if the bulk $\mathrm{O}_{2}$ of the system was open, externally imposed and shifted towards lower bulk $\mathrm{O}_{2}$ values (blue lines for $\mathrm{CdA}$ and $\mathrm{CdG}$, respectively in Fig. 2a). This hypothesis would reconcile the seemingly contradictory $\mathrm{fO}_{2}$ stemming from thermodynamic modelling, some experiments, and natural samples.

\section{Sediment-fluid infiltration driven by deserpentinisation (553 words)}

The infiltration of fluids equilibrated with metasedimentary rocks - well documented in the genesis of natural metaperidotite ${ }^{25,33,42,43}$ - is a potential mechanism for modifying the $f \mathrm{O}_{2}$ and multivalent element cargo of deserpentinisation fluids. Lowering the $f \mathrm{O}_{2}$ relative to the oxidising conditions of intrinsic deserpentinisation (Fig. 2a) requires the infiltration of fluids in equilibrium with metasedimentary rocks with a highly reducing capacity, such as graphite-bearing sediments ${ }^{44,45}$. Graphite-bearing sediments and calc-silicates subducted to eclogite facies conditions during the Alpine orogeny are widely associated with the few known natural occurrences of metaperidotite derived from high-P deserpentinisation ${ }^{33,46-48}$. Figures $2 b-e$ show the results of thermodynamic modelling of the infiltration of fluids equilibrated with graphite-bearing metapelite at a temperature $10{ }^{\circ} \mathrm{C}$ colder than the intrinsic deserpentinisation conditions in the $\mathrm{CdA}\left(650^{\circ} \mathrm{C}, 1.7 \mathrm{GPa}\right)$. At these conditions, serpentinite releases 2 wt. $\%$ of $\mathrm{H}_{2} \mathrm{O}$ and generates sufficient permeability for external fluid infiltration. The metapelite-derived infiltrating aqueous fluid is rich in $\mathrm{CH}_{4}$ and $\mathrm{H}_{2} \mathrm{~S}$ with minor $\mathrm{H}_{2}$ (Supplementary Table 2). At the onset of its infiltration into dehydrating serpentinite, $\mathrm{CH}_{4}$ is oxidised to $\mathrm{CO}_{2}$, and the $\mathrm{H}_{2} \mathrm{~S}$ and $\mathrm{H}_{2}$ concentrations decrease at the expense of more oxidised $\mathrm{HSO}_{4}{ }_{(\text {(aq) }}$ and $\mathrm{SO}_{4}{ }^{2-}$ (aq) species that increase compared to those in the intrinsic deserpentinisation fluid (Supplementary Table 2 and Fig. 5a). Sediment-fluid infiltration gradually decreases the bulk $\mathrm{Fe}^{3+} / \Sigma \mathrm{Fe}$ (Fig. 2b), thus decreasing its bulk rock 
and fluid (Fig. 2e and Supplementary Fig. 5a and Table 2). Complete dehydration occurs at isobaric and isothermal conditions with an infiltration as low as $7.4 \mathrm{~mol} / \mathrm{kg}$ of a fluid equilibrated with a graphite-bearing metapelite (vertical dashed line in Fig. 2b-e).

For an infiltration extent of 9-12 mol/kg (ca. 0.2 fluid/rock mass ratio, Fig. $2 \mathrm{~b}-\mathrm{e}$ ), sedimentequilibrated fluid infiltration driven by deserpentinisation fully succeeds in explaining many features of natural CdA serpentinite and metaperidotite, such as the trend of decreasing bulk $\mathrm{Fe}^{3+} / \Sigma \mathrm{Fe}$ (Fig. 1a; $0.17-0.10$ in Fig.2b), the relative increase in metaperidotite bulk $\mathrm{S}$ content (ca. $400-500 \mu \mathrm{g} / \mathrm{g} \mathrm{S}$, Fig. $1 \mathrm{~b}$ and $2 \mathrm{e}$ ) relative to its metaserpentinite protolith (c. $170 \mu \mathrm{g} / \mathrm{g}$ ), and the modal magnetite content (Supplementary Fig. 1) and lack of hematite in metaperidotite. It also predicts an olivine $\mathrm{X}_{\mathrm{Mg}}(0.91-$ 0.89, Fig. 2c) and $\Delta \log _{10} f \mathrm{O}_{2}[\mathrm{FMQ}]\left(+2.7\right.$ to +2.3 , Fig. 2d), in excellent agreement with the olivine $\mathrm{X}_{\mathrm{Mg}}$ of CdA metaperidotite ${ }^{4,15,35}$ and the $f \mathrm{O}_{2}$ and olivine $\mathrm{X}_{\mathrm{Mg}}$ obtained in graphite-furnace serpentinite dehydration experiments ${ }^{12}$. Compared to the intrinsic deserpentinisation, the infiltration of 9-12 mol $/ \mathrm{kg}$ of sediment-equilibrated fluids does not significantly modify the bulk major element contents, silicate mineral assemblage or modal proportions of metaperidotite. This petrological similarity likely explains why sediment-fluid infiltration has only been considered responsible for the cryptic geochemical signature of natural metaperidotite but largely passed unnoticed as a mechanism to modulate the redox state and cargo of redox-sensitive elements during deserpentinisation. For an external fluid infiltration of $>11 \mathrm{~mol} / \mathrm{kg}$, the rise of $\mathrm{H}_{2} \mathrm{~S}$ and $\mathrm{HS}^{-}$(aq) in the fluid results in pyrite precipitation (Supplementary Fig. 5b) —occasionally found in CdA metaperidotites - while maintaining an elevated concentration of $\mathrm{HSO}_{4}^{-}{ }_{\text {(aq), }}$, accounting for the observed increase of the $\mathrm{SO}_{4} / \Sigma \mathrm{S}$ ratio allied to a decrease in total $\delta^{34} \mathrm{~S}$ in metaperidotite relative to its serpentinite protolith reported in $\mathrm{CdA}^{36}$.

\section{Implications for the redox state of the subarc mantle (607 words)}

The interaction of slab fluids with the subarc mantle wedge source is increasingly recognised ${ }^{40,41}$ as the cause of the more oxidised nature of arc basalts relative to MORBs. Deserpentinisation is the main source of slab fluids at subarc depths and thus a possible mantle wedge oxidation agent. While the extent of serpentinisation of fast-spreading mid-ocean lithosphere is largely unconstrained, serpentinite is widespread in subducted slow-spreading, mid-ocean ridge lithosphere and at the slab interface of subduction zones. At the slab interface of hot to cold subduction zones, modelling shows that serpentinite intrinsically dehydrates between $2.4-3.4 \mathrm{GPa}$ and $650-660{ }^{\circ} \mathrm{C}$ under relatively oxidising conditions (+2.9 to $+3.7 \Delta \log _{10} f \mathrm{O}_{2}$ [FMQ]), particularly in hot subduction zones (see ID in Fig. 3a) due to the negative pressure dependence of $\Delta \log _{10} f_{2}$ [FMQ] for metaperidotites (Supplementary Fig. 6). The dominant fluid sulfur species in all thermal regimes is $\mathrm{HSO}^{4}{ }_{(\mathrm{aq})}$, which is slightly more abundant in deserpentinisation fluids from — relatively more oxidant — hot subduction zones (Fig. 3a). At the slab interface, serpentinite coexists with fluid-saturated metasedimentary rocks in 
(a) Slab interface

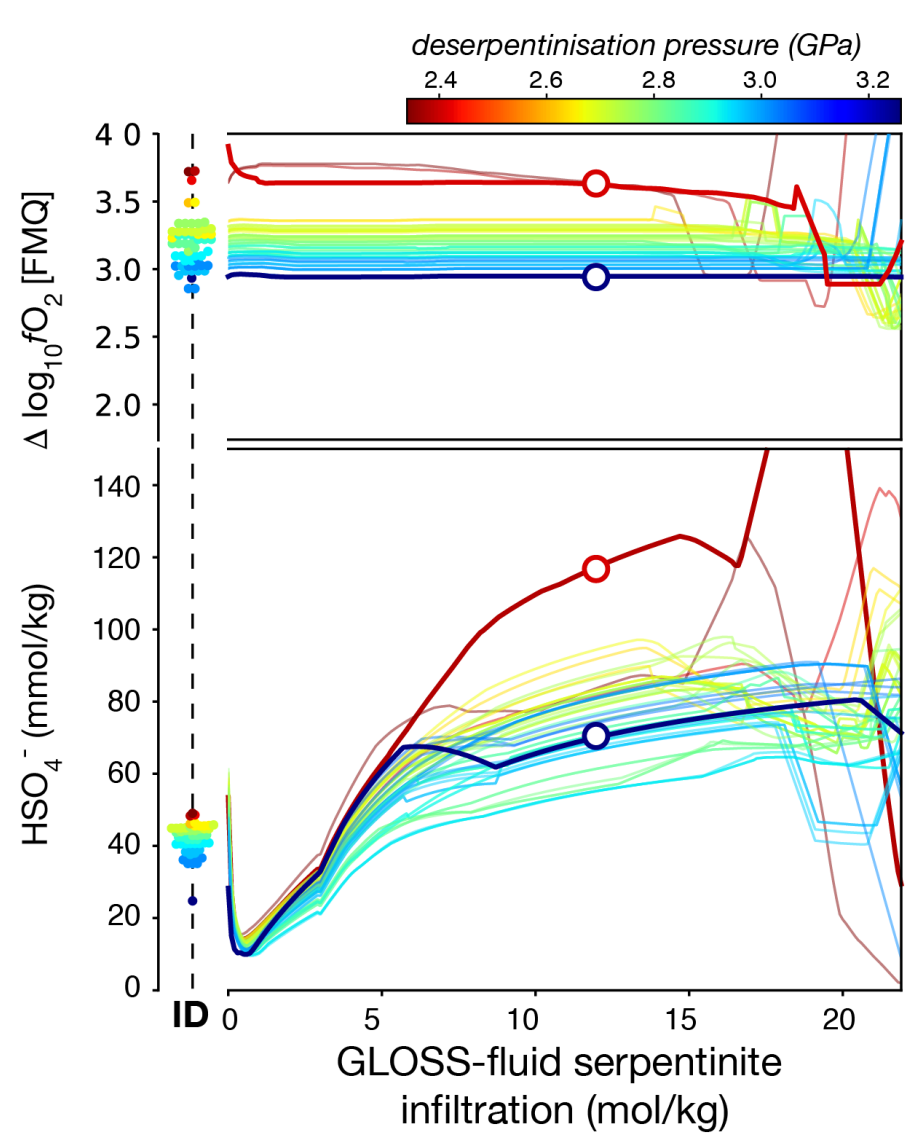

(b) Mantle Wedge
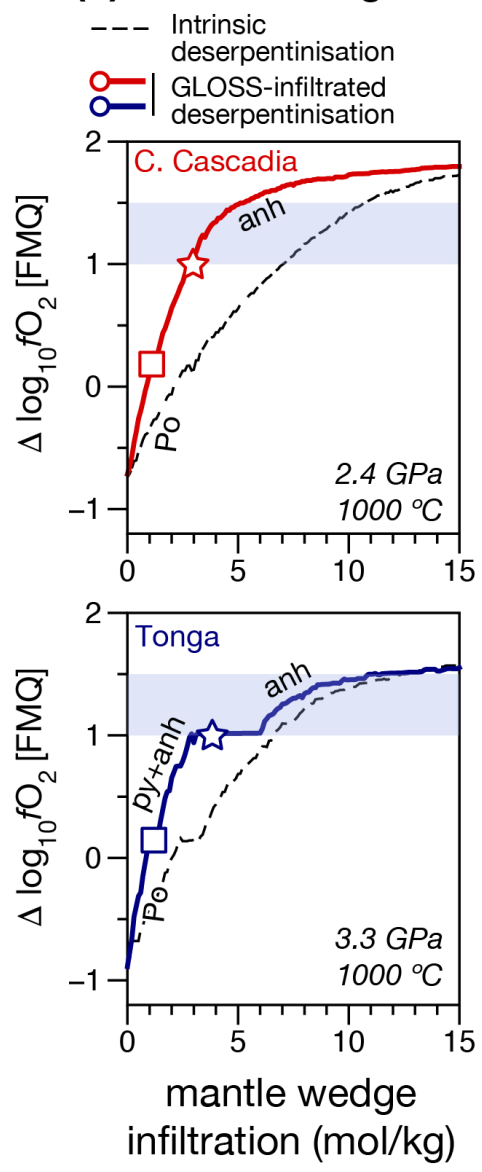

FIGURE 3a. Modification of the $\Delta \log _{10} f \mathrm{O}_{2}[\mathrm{FMQ}]$ and the concentration of the main oxidising fluid species $\left(\mathrm{HSO}_{4}^{-}\right)$relative to the intrinsic dehydration (ID) serpentinite fluid when serpentinites are infiltrated by sediment-derived fluids with low reducing capacity (GLOSS) for a worldwide compilation of subduction zones (color-coded for the pressure at which the serpentinite dehydrates at the slab surface, Methods). b. The capacity of these modified, serpentinite-derived fluids (empty dots in a) to oxidise the mantle wedge on top of the slab at near wet-solidus conditions is computed for the hottest (Central Cascadia) and coldest (Tonga) subduction zones. A minimum value range of $\Delta \log _{10} f \mathrm{O}_{2}[\mathrm{FMQ}]$ inferred for oxidised IAB source and recorded by high-pressure metasomatized mantle atop of the $\operatorname{slab}^{52,53}$ is given as a horizonal blue-shaded range. Sediment (GLOSS)serpentinite derived fluids are more than two-fold more efficient $(3 \mathrm{~mol} / \mathrm{kg}$ ) to oxidise the mantle wedge than the intrinsically-released serpentinite dehydration fluids $(7 \mathrm{~mol} / \mathrm{kg})$. The metasomatized mantle wedge has an initial depleted composition. Squares and stars on the red and blue lines indicate the condition range limits at which pyrrhotite (Po), pyrite (py) or anhydrite (anh) are the stable minerals hosting $\mathrm{S}$ in the rocks. For an ultradepleted MORB mantle see Supplementary, Fig. 7. For an interaction with sediments with high reducing capacity (blackshale-like sediments) see Supplementary Fig. 8. 
176

177

178

179

180

181

182

183

184

185

186

187

188

189

190

191

192

193

194

195

196

197

198

199

200

201

202

203

204

205

206

207

208

209

210

211

melange zones ${ }^{49}$ and sediment-fluid infiltration driven by deserpentinisation is favoured. Modelling shows that for an extent of infiltration of $12 \mathrm{~mol} / \mathrm{kg}$ - similar to that inferred from natural CdA (Fig. 2b-e) - infiltration of fluids equilibrated with modern Global Subducting Sediments (GLOSS) ${ }^{21,42}$ during deserpentinisation does not greatly modify their $\mathrm{fO}_{2}$ relative to intrinsic deserpentinisation whatever the subduction thermal regime (Fig. 3a). However, the abundance of dominant sulphate fluid species $\mathrm{HSO}_{4}^{-}{ }_{\text {(aq) }}$ increases notably in warm and hot subduction zones (Fig. 3a), boosting the redox capacity of deserpentinisation slab fluids relative to those produced by intrinsic dehydration.

Figure $3 \mathrm{~b}$ shows the modelling of the $f \mathrm{O}_{2}$ evolution of a DMM mantle wedge - at the nearvapour-saturated solidus temperature ${ }^{50}$ - infiltrated by deserpentinisation fluids for a hot (Central Cascadia) and cold (Tonga) subduction zone. Infiltration of at least $7 \mathrm{~mol} / \mathrm{kg}$ of slab fluids produced by intrinsic deserpentinisation is required to oxidise the mantle wedge within the minimum range of $\Delta \log _{10} f \mathrm{O}_{2}[\mathrm{FMQ}]$ inferred for the mantle source of arc magmas (FMQ $+1.0^{51,52}$ ). In contrast, GLOSSinfiltrated deserpentinisation fluids have a greater oxidising capacity; the interaction of about $3 \mathrm{~mol} / \mathrm{kg}$ of these slab fluids drastically increases the $\Delta \log _{10} \mathrm{O}_{2}[\mathrm{FMQ}]$ of the mantle wedge in hot and cold subduction zones (Fig. 3b). Therefore the effectiveness of rock deserpentinisation required to oxidise the mantle wedge is increased by a factor of more than two compared to intrinsic deserpentinisation. In both thermal regimes, slab fluids can attain the inferred $f \mathrm{O}_{2}$ of the mantle source of arc magmas by precipitating anhydrite, thought to be the main sulfur host at these $f \mathrm{O}_{2}$ mantle wedge conditions ${ }^{51}$. Our results demonstrate that metasomatism of the mantle wedge with GLOSS-infiltrated deserpentinisation fluids is a viable mechanism to account for the oxidised nature of the mantle source of arc magmas in hot and cold subduction zones. Similar conclusions are obtained when considering a more depleted and reduced - due to dependence of the $f \mathrm{O}_{2}$ on the peridotite bulk composition ${ }^{53}$ - mantle wedge (Supplementary Fig. 7), indicating that the extent of mantle wedge depletion has a subsidiary role compared to the redox capacity of the incoming slab fluids.

As attested by natural metaperidotite, the oxidising capacity of sediment-infiltrated deserpentinisation fluids depends on the redox capacity of subducted sediments. This capacity has changed throughout Earth's geological history linked to the oxidation state of the atmosphere-ocean system and varies from oxidant GLOSS ${ }^{28,54}$ to highly reducing black shales ${ }^{44,45}$. Modelling of deserpentinisation infiltrated by fluids equilibrated with graphite-bearing metapelite shows that in hot subduction zones the oxidant capacity of fluids is as high as for intrinsic deserpentinisation but is significantly lower for cold subduction zones (Supplementary Fig. 7 and 8).

\section{References}

1. Lécuyer, C. \& Ricard, Y. Long-term fluxes and budget of ferric iron: Implication for the redox states of the Earth's mantle and atmosphere. Earth Planet. Sci. Lett. 165, 197-211 (1999).

2. Evans, K. A. The redox budget of subduction zones. Earth-Science Rev. 113, 11-32 (2012). 
212 3. Alt, J. C. et al. The role of serpentinites in cycling of carbon and sulfur: Seafloor serpentinization and

213 subduction metamorphism. Lithos 178, 40-54 (2013).

214 4. Bretscher, A., Hermann, J. \& Pettke, T. The influence of oceanic oxidation on serpentinite dehydration 215 during subduction. Earth Planet. Sci. Lett. 499, 173-184 (2018).

216 5. Debret, B. et al. Redox transfer at subduction zones: insights from Fe isotopes in the Mariana forearc. 217 Geochem. Persp. Let 12, 46-51 (2020).

218 6. Maurice, J. et al. The intrinsic nature of antigorite breakdown at $3 \mathrm{GPa}$ : Experimental constraints on redox conditions of serpentinite dehydration in subduction zones. Contrib. to Mineral. Petrol. 175, 94 (2020).

7. Evans, K. A. \& Frost, B. R. Deserpentinization in Subduction Zones as a Source of Oxidation in Arcs: a Reality Check. J. Petrol. 62, 1-32 (2021).

8. Debret, B. \& Sverjensky, D. A. Highly oxidising fluids generated during serpentinite breakdown in subduction zones. Sci. Rep. 7, 1-6 (2017).

9. Evans, K. A., Powell, R. \& Holland, T. J. B. Internally consistent data for sulphur-bearing phases and application to the construction of pseudosections for mafic greenschist facies rocks in $\mathrm{Na}_{2} \mathrm{O}-\mathrm{CaO}-\mathrm{K}_{2} \mathrm{O}-$ $\mathrm{FeO}-\mathrm{MgO}-\mathrm{Al}_{2} \mathrm{O}_{3}-\mathrm{SiO}_{2}-\mathrm{CO}_{2}-\mathrm{O}-\mathrm{S}-\mathrm{H}_{2} \mathrm{O}$. J. Metamorph. Geol. 28, 667-687 (2010).

10. Evans, K. A. \& Powell, R. The effect of subduction on the sulphur, carbon and redox budget of lithospheric mantle. J. Metamorph. Geol. 33, 649-670 (2015).

11. Evans, K. A., Reddy, S. M., Tomkins, A. G., Crossley, R. J. \& Frost, B. R. Effects of geodynamic setting on the redox state of fluids released by subducted mantle lithosphere. Lithos 278-281, 26-42 (2017).

12. Iacovino, K., Guild, M. R. \& Till, C. B. Aqueous fluids are effective oxidizing agents of the mantle in subduction zones. Contrib. to Mineral. Petrol. 20201754 175, 1-21 (2020).

13. Li, J. L. et al. Uncovering and quantifying the subduction zone sulfur cycle from the slab perspective. Nat. Commun. 11, (2020).

14. Merkulova, M. V et al. Experimental insight into redox transfer by iron- and sulfur-bearing serpentinite dehydration in subduction zones. Earth Planet. Sci. Lett. 479, 133-143 (2017).

15. Piccoli, F. et al. Subducting serpentinites release reduced, not oxidized, aqueous fluids. Sci. Rep. 9,

16. Debret, B. et al. Redox state of iron during high-pressure serpentinite dehydration. Contrib. to Mineral. Petrol. 169, 1-18 (2015).

17. Mayhew, L. E. \& Ellison, E. T. A synthesis and meta-analysis of the Fe chemistry of serpentinites and serpentine minerals. Philos. Trans. R. Soc. A Math. Phys. Eng. Sci. 378, 20180420 (2020).

18. Andreani, M., Muñoz, M., Marcaillou, C. \& Delacour, A. $\mu$ XANES study of iron redox state in serpentine during oceanic serpentinization. Lithos 178, 70-83 (2013).

19. O'Neill, H. S. C. et al. Ferric Iron in the Upper Mantle and In Transition Zone Assemblages: Implications for Relative Oxygen Fugacities in the Mantle. in 73-88 (American Geophysical Union (AGU), 2013). doi:10.1029/GM074p0073. metallogeny. Lithos vol. 233 27-45 (2014). 
21. Frost, R. \& Ballhaus, C. Comment on "“Constraints on the origin of the oxidation state of mantle overlying subduction zones: An example from Simcoe, Washington, USA”, by A. D. Brandon and D. S. Draper. Geochim. Cosmochim. Acta 62, 329-331 (1998).

22. Rielli, A. et al. Evidence of sub-arc mantle oxidation by sulphur and carbon. Lett. Geochemical Perspect. Lett. Geochem. Persp. Let 3, 124-132 (2017).

23. Colin, A. et al. In situ determination of sulfur speciation and partitioning in aqueous fluid-silicate melt systems. Geochemical Perspect. Lett. 31-35 (2020) doi:10.7185/geochemlet.2020.

24. Vieira Duarte, J. F., Piccoli, F., Pettke, T. \& Hermann, J. Textural and geochemical evidence for magnetite production upon antigorite breakdown during subduction. J. Petrol. (2021) doi:10.1093/petrology/egab053.

25. Garrido, C. J. et al. Enrichment of HFSE in chlorite-harzburgite produced by high-pressure dehydration of antigorite-serpentinite: Implications for subduction magmatism. Geochemistry Geophys. Geosystems 6, (2005).

26. Scambelluri, M., Pettke, T., Rampone, E., Godard, M. \& Reusser, E. Petrology and Trace Element Budgets of High-pressure Peridotites Indicate Subduction Dehydration of Serpentinized Mantle (Cima di Gagnone, Central Alps, Switzerland). J. Petrol. 55, 459-498 (2014).

27. Debret, B. et al. Iron and zinc stable isotope evidence for open-system high-pressure dehydration of antigorite serpentinite in subduction zones. Geochim. Cosmochim. Acta 296, 210-225 (2021).

28. Plank, T. \& Langmuir, C. H. Tracing trace elements from sediment input to volcanic output at subduction zones. Nature 362, 739-743 (1993).

29. Scambelluri, M. et al. The fate of $\mathrm{B}, \mathrm{Cl}$ and $\mathrm{Li}$ in the subducted oceanic mantle and in the antigorite breakdown fluids. Earth Planet. Sci. Lett. 222, 217-234 (2004).

30. John, T., Scambelluri, M., Frische, M., Barnes, J. D. \& Bach, W. Dehydration of subducting serpentinite: Implications for halogen mobility in subduction zones and the deep halogen cycle. Earth Planet. Sci. Lett. 308, 65-76 (2011).

31. Kendrick, M. A., Scambelluri, M., Hermann, J. \& Padrón-Navarta, J. A. Halogens and noble gases in serpentinites and secondary peridotites: Implications for seawater subduction and the origin of mantle neon. Geochim. Cosmochim. Acta 235, 285-304 (2018).

32. Harvey, J. et al. 11B-rich fluids in subduction zones: The role of antigorite dehydration in subducting slabs and boron isotope heterogeneity in the mantle. Chem. Geol. 376, 20-30 (2014).

33. Marchesi, C., Garrido, C. J., Padrón-Navarta, J. A., López Sánchez-Vizcaíno, V. \& Gómez-Pugnaire, M. T. Element mobility from seafloor serpentinization to high-pressure dehydration of antigorite in subducted serpentinite: Insights from the Cerro del Almirez ultramafic massif (southern Spain). Lithos 178, 128-142 (2013).

34. Lazar, C. Using Silica Activity to Model Redox-dependent Fluid Compositions in Serpentinites from 100 to $700^{\circ} \mathrm{c}$ and from 1 to 20 kbar. J. Petrol. 61, (2020).

35. Padrón-Navarta, J. A. et al. Metamorphic record of high-pressure dehydration of antigorite serpentinite to chlorite harzburgite in a subduction setting (Cerro del Almirez, Nevado-Filábride complex, Southern Spain). J. Petrol. 52, 2047-2078 (2011).

36. Alt, J. C. et al. Recycling of water, carbon, and sulfur during subduction of serpentinites: A stable 
isotope study of Cerro del Almirez, Spain. Earth Planet. Sci. Lett. 327-328, 50-60 (2012).

293

37. Padrón-Navarta, J. A. et al. Tschermak's substitution in antigorite and consequences for phase relations and water liberation in high-grade serpentinites. Lithos 178, 186-196 (2013).

38. Padrón-Navarta, J. A., Hermann, J., Garrido, C. J., López Sánchez-Vizcaíno, V. \& Gómez-Pugnaire, M. T. An experimental investigation of antigorite dehydration in natural silica-enriched serpentinite. Contrib. to Mineral. Petrol. 159, 25-42 (2010).

39. Bromiley, G. D. \& Pawley, A. R. The stability of antigorite in the systems $\mathrm{MgO}-\mathrm{SiO}_{2}-\mathrm{H}_{2} \mathrm{O}(\mathrm{MSH})$ and $\mathrm{MgO}-\mathrm{Al}_{2} \mathrm{O}_{3}-\mathrm{SiO}_{2}-\mathrm{H}_{2} \mathrm{O}$ (MASH): The effects of $\mathrm{Al} 3+$ substitution on high-pressure stability. Am. Mineral. 88, 99-108 (2003).

40. Truckenbrodt, J., Ziegenbein, D. \& Johannes, W. Redox conditions in piston-cylinder apparatus: The different behavior of boron nitride and unfired pyrophyllite assemblies. Am. Mineral. 82, 337-344 (1997).

41. Evans, B. W. \& Trommsdorff, V. Petrogenesis of garnet lherzolite, Cima di Gagnone, Lepontine Alps. Earth Planet. Sci. Lett. 40, 333-348 (1978).

42. Scambelluri, M., Pettke, T. \& Cannaò, E. Fluid-related inclusions in Alpine high-pressure peridotite reveal trace element recycling during subduction-zone dehydration of serpentinized mantle (Cima di Gagnone, Swiss Alps). Earth Planet. Sci. Lett. 429, 45-59 (2015).

43. Cannaò, E., Agostini, S., Scambelluri, M., Tonarini, S. \& Godard, M. B, Sr and Pb isotope geochemistry of high-pressure Alpine metaperidotites monitors fluid-mediated element recycling during serpentinite dehydration in subduction mélange (Cima di Gagnone, Swiss Central Alps). Geochim. Cosmochim. Acta 163, 80-100 (2015).

44. Galvez, M. E., Fischer, W. W., Jaccard, S. L. \& Eglinton, T. I. Materials and pathways of the organic carbon cycle through time. Nat. Geosci. 13, 535-546 (2020).

45. Galvez, M. E. \& Jaccard, S. L. Reducing capacity of rocks by high temperature chalcometric titration. Chem. Geol. 120016 (2020) doi:10.1016/j.chemgeo.2020.120016.

46. Augier, R. et al. Exhumation constraints for the lower Nevado-Filabride Complex (Betic Cordillera, SE Spain): a Raman thermometry and Tweequ multiequilibrium thermobarometry approach. Bull. La Soc. Geol. Fr. 176, 403-416 (2005).

47. Connolly, J. A. D. Computation of phase equilibria by linear programming: A tool for geodynamic modeling and its application to subduction zone decarbonation. Earth Planet. Sci. Lett. 236, 524-541 (2005).

48. Kuhn, B. K., Reusser, E., Powell, R. \& Günther, D. Metamorphic evolution of calc-schists in the Central Alps, Switzerland. Schweizerische Mineral. und Petrogr. Mitteilungen 85, 175-190 (2005).

49. Bebout, G. E. \& Penniston-Dorland, S. C. Fluid and mass transfer at subduction interfaces-The field metamorphic record. Lithos 240-243, 228-258 (2016).

50. Green, D. H., Hibberson, W. O., Kovacs, I. \& Rosenthal, A. Water and its influence on the lithosphereasthenosphere boundary. Nature 467, (2010).

51. Bénard, A. et al. Oxidising agents in sub-arc mantle melts link slab devolatilisation and arc magmas. Nat. Commun. 9, (2018).

52. Malaspina, N., Poli, S. \& Fumagalli, P. The Oxidation State of Metasomatized Mantle Wedge: Insights 

from C-O-H-bearing Garnet Peridotite. J. Petrol. 50, 1533-1552 (2009).

333 53. Stolper, E. M., Shorttle, O., Antoshechkina, P. M. \& Asimow, P. D. The effects of solid-solid phase equilibria on the oxygen fugacity of the upper mantle. Am. Mineral. 105, 1445-1471 (2020).

335 54. Plank, T. \& Langmuir, C. H. The chemical composition of subducting sediment and its consequences for the crust and mantle. Chem. Geol. 145, 325-394 (1998).

337 


\section{Methods}

340 Abundance of redox-sensitive elements. We extended a previous compilation ${ }^{17}$ of ferric and ferrous 341 iron contents in serpentinite from different geologic settings $(n=758)$ (Fig.1a) to include alpine 342 serpentinite from Malenco (N. Italy, $\mathrm{n}=42)^{55,56}$ and 33 new analyses from CdA analysed by 343 potentiometric titration. Bulk $\mathrm{Fe}^{3+} / \Sigma \mathrm{Fe}$ ratios are in excellent agreement with mineral mode estimates

344 based on the measured amount of magnetite by saturation magnetization corrected for the paramagnetic 345 fraction ${ }^{16}$ and using the $\mathrm{Fe}^{3+} / \Sigma \mathrm{Fe}$ content of antigorite measured by XANES spectroscopy in selected 346 samples $^{57}$. Magnetite contents (Supplementary Fig. 2) comprise serpentinites from mid-ocean ridges 347 (ODP Leg 153 MARK $^{18,58,59}$ ), passive margins (ODP Leg 173 Iberia $^{58,59}$ ), Puerto Rico Trench 348 (NWPRT) $)^{59}$, forearc (ODP Leg 125 Marianas $^{58,59}$ ), alpine serpentinites ${ }^{16,35,57}$, and prograde 349 metaperidotite from $\mathrm{CdA}^{4,35,57}$ and $\mathrm{CdG}^{41}$. Late-stage weathering of prograde metaperidotite may cause 350 re-oxidation during hydration, therefore we only consider samples with $<4.5 \mathrm{wt} . \% \mathrm{H}_{2} \mathrm{O}$ for comparison 351 with the thermodynamic predictions (Fig.1). Bulk carbon and sulphur contents are from this study and 352 $\operatorname{ref}^{2,11,36,41,60}$.

353

354 Computation of redox budget. The redox budget ${ }^{61}$ is an extensive variable quantifying the ability of 355 a rock-fluid system to potentially induce oxidation or reduction relative to an arbitrary reference redox state of interest. The specific redox budget (RB) is normalized to units of $\mathrm{mol} / \mathrm{kg}$ and it is defined as, $\mathrm{RB}=\sum_{\mathrm{j}} \mathrm{n}_{\mathrm{j}} \cdot \mathrm{v}_{\mathrm{j}}$ where $\bar{v}_{\mathrm{j}}$ is the number of electrons required to take one mole of the element in the redox state $j$ to the reference redox state, and $\mathbf{n}_{\mathrm{j}}$ is the number of moles per $\mathrm{kg}$ of the element in the redox state $j$ present in the system (rock and fluid). Here (Supplementary Table 1 and Fig. 3), we consider the redox budget of the solid rock as this is the only variable that can be measured after fluid extraction. For the whole mantle reference redox state ${ }^{2}$, the oxidation state of iron, carbon and sulphur are $\mathrm{Fe}^{2+}, \mathrm{C}^{0}$ and $\mathrm{S}^{2-}$, respectively, resulting in $\mathrm{V}_{\mathrm{j}}$ of $1,-2,4,1$ and 8 for $\mathrm{Fe}^{3+}, \mathrm{Fe}^{0}, \mathrm{C}^{4+}, \mathrm{S}^{-}$and $\mathrm{S}^{6+}$. In the modelled system, the $\mathrm{RB}$ is computed based on the number of moles per $\mathrm{kg}$ of rock of the phases containing $\mathrm{Fe}^{3+}, \mathrm{Fe}^{0}$, $\mathrm{C}^{4+}, \mathrm{S}^{-}$or $\mathrm{S}^{6+}$ (hematite, native iron, magnesite, dolomite, calcite, pyrite, pyrrhotite, pyroxenes, garnet and anhydrite, Supplementary Fig. 3) multiplied by the number of redox-sensitive atoms in their structural formulae. For mineral phases having ferric iron in solid solution, the RB is weighted by the molar proportion of the ferric iron endmember (magnetite in spinel ${ }^{62}, \mathrm{Fe}_{0.875} \mathrm{~S}$ in pyrrhotite ${ }^{9}$, magnesium ferri-tschermak's in orthopyroxene modified by J.A.D. Connolly from ref ${ }^{63}$, and khoharite in garnet $\left.{ }^{64}\right)$.

371 Phase equilibria. Phase equilibria and electrolyte fluid speciation were computed by Gibbs energy minimization using the PerpleX algorithm ${ }^{65,66}$. Forward thermodynamic modelling has been performed in the CFMACrSHCSO system using elements as thermodynamic system components ( $\mathrm{Ca}-\mathrm{Fe}-\mathrm{Mg}-$ 
$375\left(\mathrm{Na}-\mathrm{K}-\mathrm{Ca}-\mathrm{Fe}-\mathrm{Mg}-\mathrm{Al}-\mathrm{Cr}-\mathrm{Si}-\mathrm{H}_{2}-\mathrm{C}-\mathrm{S}_{2}-\mathrm{O}_{2}\right)$ for the graphite-bearing metapelite ${ }^{33,46}$ and GLOSS ${ }^{54}$, as 376 well as for the metasomatic infiltration models derived from them (bulk composition used are in 377 Supplementary Table 1). Fluid saturation conditions were not imposed during the computation. Element 378 components are preferred over oxide components when modelling electrolytic fluid speciation because $379 \mathrm{C}-\mathrm{O}-\mathrm{H}-\mathrm{S}$ solvents in the fluid have a strong tendency to order for certain bulk compositions at low 380 temperature ${ }^{67}$. Thermodynamic data for endmembers are taken from ref ${ }^{68}$. Considered solid solutions

381

382

383

384

385

386

387

388

389

390

391

392

393

394

395

396

397

398

399

400

401

402

403

404

405

406

407

408

409

410 models were olivine (Ol), orthopyroxene (Opx), clinopyroxene ( $\mathrm{Cpx})$, chlorite $(\mathrm{Chl})$, dolomite (Dol), magnesite (Mgs), epidote (Ep), staurolite (St), all of them from $\mathrm{ref}^{69,70}$, pyrrhotite $(\mathrm{Po})^{68}$, amphibole $(\mathrm{Amph}(\mathrm{DHP}))^{71}$, garnet $(\mathrm{Grt}(\mathrm{WPH}))^{64}$, antigorite $(\mathrm{Atg})^{37}$, white mica $(\operatorname{mica}(\mathrm{CF}))^{72}$, biotite $(\mathrm{Bi}(\mathrm{WPH}))^{64}$, feldspar $^{73}$, Cr-bearing spinel (Mag) ${ }^{62}$, talc (Tlc, ideal), brucite (B, ideal), anthophyllite (Anth, ideal), and pure endmembers hematite (hem), pyrite (py), anhydrite (anh), graphite (gr), quartz (q) and iron. We used models $\mathrm{Chl}(\mathrm{W})^{74}$ and $\mathrm{Cpx}(\mathrm{HGP})^{75}$ for graphite-bearing metapelite and GLOSS, whereas for the mantle wedge metasomatism modelling we used solid solution models specifically calibrated for the mantle ${ }^{62}$. The systems considered in our work allow the investigation of redox reactions among the $\mathrm{Fe}-\mathrm{C}-\mathrm{S}$-bearing solid phases (pyrrhotite, pyrite, anhydrite, magnetite, hematite, iron, carbonates and graphite) and species (e.g. $\mathrm{HS}^{-}, \mathrm{SO}_{4}{ }^{2-}, \mathrm{CaSO}_{4(\mathrm{aq})}$ among many others) in an electrolyte aqueous $\mathrm{C}-\mathrm{O}-\mathrm{H}-\mathrm{S}$ fluid. Non-modelled components (Ti, Mn and Ni) typically represent less than 0.5 wt.\% (expressed as oxides) of the bulk rock composition. The absence of titanium and nickel prevents the modelling of phase assemblages containing ilmenite and pentlandite which typically occur in excess in high-pressure serpentinite and metaperidotites. The initial oxidation state of the redox-sensitive elements $\left(\mathrm{Fe}-\mathrm{C}-\mathrm{S}_{2}\right)$ is specified by the amount of $\mathrm{O}_{2}$ in the system and requires a knowledge of the oxidation state of iron, carbon and sulphur (Supplementary, Table 1). However, the oxidation state of iron, carbon and sulphur are not imposed but are set by the stable phases obtained by Gibbs energy minimization (Supplementary Fig. 2 and 3). The geothermal gradient used to compute Fig. 2 and Supplementary Fig. 2-4) (P[bar $]=-18057+37.9357 * \mathrm{~T}[\mathrm{~K}])$ follows the P-T path inferred for $\mathrm{CdA}^{76}$, and also applies for peak metamorphic conditions estimated for the $\mathrm{CdG}$ metaperidotite ${ }^{41}$.

Solvent and speciation in the aqueous fluid. The neutrally charged solvent molecules considered in the fluid were $\mathrm{H}_{2} \mathrm{O}-\mathrm{CO}_{2}-\mathrm{CH}_{4}-\mathrm{H}_{2}-\mathrm{H}_{2} \mathrm{~S}$ (thermodynamic data from ref. ${ }^{68}$ ) described by a generic hybrid fluid EoS with non-linear subdivision (COH-Fluid+ from $\mathrm{ref}^{67}$ ). The EoS for $\mathrm{H}_{2} \mathrm{O}$ and $\mathrm{CO}_{2}$ is $\mathrm{PSEoS}^{77}$, whereas for other solvents is the $\mathrm{MRK}^{78}$. All other species are taken as solutes following the approach of ref. ${ }^{67,79}$ (see Supplementary Table 2). Thermodynamic data for aqueous species are taken from the latest version of the DEW model ${ }^{80}$. The species $\mathrm{CO}_{(\mathrm{aq})}$ and $\mathrm{SO}_{2(\mathrm{aq})}$ are considered as solute species in the fluid, although they occur at very low concentrations (Supplementary Table 2). Organic species from the DEW model were excluded from the computation following $\operatorname{ref}^{67}$. The $\mathrm{Mg}\left(\mathrm{SiO}_{2}\right)\left(\mathrm{HCO}_{3}\right)^{+}$and $\mathrm{H}_{2} \mathrm{CO}_{3(\mathrm{aq})}$ species were also excluded as they were found to result in unrealistically high concentrations. 
411 Back- and lagged-computation methods ${ }^{67}$ give similar results at temperatures cooler than the complete

412 serpentinite breakdown, but only the lagged method correctly models the complete loss of sulphur at

413 higher temperatures because this method imposes mass balance conservation.

415 Infiltration models. The fluids in equilibrium with the graphite-bearing metapelite were first computed 416 by Gibbs energy minimization at the $\mathrm{P}-\mathrm{T}$ conditions of interest $\left(650^{\circ} \mathrm{C}, 1.7 \mathrm{GPa}\right.$, Supplementary Table 417 2) using MEEMUM from the PerpleX package ${ }^{66}$ and the lagged calculation method ${ }^{67}$. This composition 418 (renormalized to two hydrogen moles) was then equilibrated with the model serpentinite at the same $\mathrm{P}-$ $419 \mathrm{~T}$ conditions at steps of $0.1 \mathrm{~mol}$ of fluid aliquot along 150 nodes ( 0 -d infiltration mode), without 420 fractionation of the fluid at each node. Additional computations fractionating the fluid at each node do 421 not significantly modify the results. An example of the reequilibrated composition after interaction of $42212 \mathrm{~mol} / \mathrm{kg}$ with a fluid equilibrated with graphite-bearing metapelite is presented in the Supplementary 423 Table 2. To model global subduction zones, the same procedure was repeated for all s 56 subduction 424 zone segments at the $\mathrm{P}$ and $\mathrm{T}$ of the intersection of the antigorite breakdown with the slab surface based 425 on the numerical model D80 from ref. ${ }^{81}$ The intersection was found by solving the polynomial fitting 426 of the antigorite dehydration curve from this study and the slab trajectories at the surface ${ }^{81}$ as 427 documented in ref. ${ }^{82}$. MEEMUM was then computed for the $56 \mathrm{P}-\mathrm{T}$ conditions for the two different 428 fluid sources (graphite-bearing metapelite and GLOSS sediment) resulting in 112 different fluid 429 compositions. Once these fluids were retrieved, 112 infiltration models were run with VERTEX at the 430 specified $\mathrm{P}-\mathrm{T}$ conditions. These computations generate multigrid outputs for all available properties accessible with WERAMI, including, mineral and fluid modes, dependent chemical potentials (used to compute $\Delta \log _{10} f \mathrm{O}_{2}[\mathrm{FMQ}]$ ) and the amount of solvents in the fluid (as mole fraction) and species concentration (as molalities, mol $/ \mathrm{kg}$ ). We provide a global dataset (source data) including $\Delta \log _{10} f \mathrm{O}_{2}[\mathrm{FMQ}]$, bulk fluid composition and solvent-solute fluid composition for the intrinsic and the two sediment-infiltrated deserpentinisation models (using high and low reducing capacity fluids) for the 56 subduction transects and an extent of interaction of $12 \mathrm{~mol} / \mathrm{kg}$. A Python notebook is provided under request to generate the dataset for any desired extent of interaction.

Mantle wedge redox conditions. Two end-member bulk compositions were considered to compute the $f \mathrm{O}_{2}$ of the mantle wedge before fluid infiltration (Fig. 3 and Supplementary Fig. 6): depleted MORB mantle source $(\mathrm{DMM})^{83}$ with a $\mathrm{Fe}^{3+} / \Sigma \mathrm{Fe}$ equal to 0.035 , taken from the Primitive Upper Mantle, and adding S content of $119 \mu \mathrm{g} / \mathrm{g}$; and a highly depleted mantle (sample PHN5239 from ref. ${ }^{84}$ ) with a $\mathrm{Fe}^{3+} / \Sigma \mathrm{Fe}$ equal to 0.021 and a $50 \mu \mathrm{g} / \mathrm{g}$ of $\mathrm{S}$, taken as the lowest possible bound based on the $\mathrm{Cu}-\mathrm{S}$ covariance in MORBs ${ }^{85}$. We chose fluids from the hottest and coldest subduction zones after $12 \mathrm{~mol} / \mathrm{kg}$ interaction of the two fluids (graphite-bearing metapelite and GLOSS) with the reference serpentinite. 
446 The aqueous fluid was fractionated at each node for mantle wedge infiltration models to reflect the low

447 instantaneous fluid-rock ratio expected for pervasive fluid flow at mantle conditions.

\section{Acknowledgements}

450 This work is part of the project DESTINE (PID2019-105192GB-I00) funded by 451 MICIN/AEI/10.13039/501100011033 and the FEDER program "una manera de hacer Europa".

452 J.A.P.N. acknowledges a Ramón y Cajal contract (RYC2018-024363-I) funded by 453 MICIN/AEI/10.13039/501100011033 and the FSE program "FSE invierte en tu futuro". This research 454 is part of the Junta de Andalucia research group RNM-131.

455

\section{Author contributions}

457 J.A.P.N. conceived the project, processed the data, acquired funding and wrote the original manuscript.

458 V.L.S-V. contributed to the conceptualization, performed the computations, organized the raw data and 459 contributed to the writing of the manuscript. M.D.M. computed the global deserpentinisation conditions 460 and assisted computations. M.T.G-P. contributed to the writing of the manuscript. C.J.G contributed to 461 the conceptualization, acquired funding, $t$ and writing of the manuscript.

462

463

\section{References}

464 55. Clément, M., Padrón-Navarta, J. A. \& Tommasi, A. Interplay between Fluid Extraction Mechanisms and Antigorite Dehydration Reactions (Val Malenco, Italian Alps). J. Petrol. 60, 1935-1962 (2019).

56. Lafay, R., Baumgartner, L. P., Putlitz, B. \& Siron, G. Oxygen isotope disequilibrium during serpentinite dehydration. Terra Nov. 31, 94-101 (2019).

469

57. Debret, B. et al. Evolution of Fe redox state in serpentine during subduction. Earth Planet. Sci. Lett.

400, 206-218 (2014).

470 58. Klein, F. et al. Magnetite in seafloor serpentinite-Some like it hot. Geology 42, 135-138 (2014).

471 59. Klein, F., Marschall, H. R., Bowring, S. A., Humphris, S. E. \& Horning, G. Mid-ocean Ridge Serpentinite in the Puerto Rico Trench: from Seafloor Spreading to Subduction. J. Petrol. 58, 17291754 (2017).

60. Paulick, H. et al. Geochemistry of abyssal peridotites (Mid-Atlantic Ridge, $15^{\circ} 20^{\prime} \mathrm{N}$, ODP Leg 209): Implications for fluid/rock interaction in slow spreading environments. Chem. Geol. 234, 179-210 (2006).

61. Evans, K. A. Redox decoupling and redox budgets: Conceptual tools for the study of earth systems. Geology 34, 489-492 (2006).

62. Jennings, E. S. \& Holland, T. J. B. B. A simple thermodynamic model for melting of peridotite in the applied to solid solutions. Am. Mineral. 81, 1425-1437 (1996).

64. White, R. W., Powell, R. \& Holland, T. J. B. Progress relating to calculation of partial melting equilibria 
for metapelites. J. Metamorph. Geol. 25, 511-527 (2007).

485

486

487

488

489

490

491

492

493

494

495

496

497

498

499

500

501

502

503

504

505

506

507

508

509

510

511

512

513

514

515

516

517

518

519

520

521

522

523

65. Connolly, J. A. D. Multivariable Phase-Diagrams - an Algorithm Based on Generalized Thermodynamics. Am. J. Sci. 290, 666-718 (1990).

66. Connolly, J. A. D. The geodynamic equation of state: What and how. Geochemistry, Geophys. Geosystems 10, (2009).

67. Connolly, J. A. D. \& Galvez, M. E. Electrolytic fluid speciation by Gibbs energy minimization and implications for subduction zone mass transfer. Earth Planet. Sci. Lett. 501, 90-102 (2018).

68. Holland, T. J. B. \& Powell, R. An improved and extended internally consistent thermodynamic dataset for phases of petrological interest, involving a new equation of state for solids. J. Metamorph. Geol. nono (2011) doi:10.1111/j.1525-1314.2010.00923.x.

69. Holland, T., Baker, J. \& Powell, R. Mixing properties and activity-composition relationships of chlorites in the system $\mathrm{MgO}-\mathrm{FeO}-\mathrm{Al}_{2} \mathrm{O}_{3}-\mathrm{SiO}_{2}-\mathrm{H} 2 \mathrm{O}$. vol. 10

http://pubs.geoscienceworld.org/eurjmin/articlepdf/10/3/395/4000281/395_gseurjmin_10_3_395_406_holland.pdf(1998).

70. Holland, T. J. B., Powell, R., Sciences, E. \& Cb, C. An internally consistent thermodynamic data set for phases of petrological interest. J. Metamorph. Geol. 16, 309-343 (1998).

71. Dale, J., Holland, T. \& Powell, R. Hornblende-garnet-plagioclase thermobarometry: a natural assemblage calibration of the thermodynamics of hornblende. Contrib. to Mineral. Petrol. V140, 353362 (2000).

72. Chatterjee, N. D. \& Froese, E. A thermodynamic study of the pseudobinary join muscovite-paragonite in the system KAlSi3O8 - NaAlSi3O8 - Al2O3 - SiO2 - H2O. Am. Mineral. 60, 985-993 (1975).

73. Fuhrman, M. L. \& Lindsley, D. H. Ternary-Feldspar Modeling and Thermometry. Am. Mineral. 73, 201-215 (1988).

74. White, R. W., Powell, R. \& Johnson, T. E. The effect of Mn on mineral stability in metapelites revisited: New a-x relations for manganese-bearing minerals. J. Metamorph. Geol. 32, 809-828 (2014).

75. Holland, T. J. B., Green, E. C. R. \& Powell, R. Melting of Peridotites through to Granites: A Simple Thermodynamic Model in the System KNCFMASHTOCr. J. Petrol. 59, 881-900 (2018).

76. Laborda-López, C. et al. High- P metamorphism of rodingites during serpentinite dehydration (Cerro del Almirez, Southern Spain): Implications for the redox state in subduction zones. J. Metamorph. Geol. 36, 1141-1173 (2018).

77. Pitzer, K. S. \& Sterner, S. M. Equations of state valid continuously from zero to extreme pressures with $\mathrm{H} 2 \mathrm{O}$ and $\mathrm{CO} 2$ as examples. Int. J. Thermophys. 16, 511-518 (1995).

78. Connolly, J. A. D. \& Cesare, B. C-O-H-S fluid composition and oxygen fugacity in graphitic metapelites. J. Metamorph. Geol. 11, 379-388 (1993).

79. Galvez, M. E., Connolly, J. A. D. \& Manning, C. E. Implications for metal and volatile cycles from the pH of subduction zone fluids. Nature 539, 420 (2016).

80. Huang, F. \& Sverjensky, D. A. Extended Deep Earth Water Model for predicting major element mantle metasomatism. Geochim. Cosmochim. Acta 254, 192-230 (2019).

81. Syracuse, E. M., van Keken, P. E. \& Abers, G. A. The global range of subduction zone thermal models. Phys. Earth Planet. Inter. 183, 73-90 (2010). 
524 82. Menzel, M. D., Garrido, C. J. \& López Sánchez-Vizcaíno, V. Fluid-mediated carbon release from serpentinite-hosted carbonates during dehydration of antigorite-serpentinite in subduction zones. Earth Planet. Sci. Lett. 531, 115964 (2020).

527 83. Salters, V. J. M. \& Stracke, A. Composition of the depleted mantle. Geochemistry, Geophys. Geosystems 5, (2004).

529 84. Canil, D. et al. Ferric iron in peridotites and mantle oxidation states. Earth Planet. Sci. Lett. 123, 205220 (1994).

531 85. Ding, S. \& Dasgupta, R. The fate of sulfide during decompression melting of peridotite - implications for sulfur inventory of the MORB-source depleted upper mantle. Earth Planet. Sci. Lett. 459, 183-195 (2017).

534 86. Eberhard, L. Serpentinite phase relations - An experimental study on redox conditions and fluid migration in subduction zones. Bayreuth, 2021 . - VIII, 258 P. (Doctoral thesis, 2020 , University of Bayreuth, Faculty of Biology, Chemistry and Earth Sciences) and redox evolution of the supra-subduction mantle. Geosphere 14, 2311-2336 (2018). 
541 Supplementary figures and tables

542 Figure 1. Global compilation of magnetite content in serpentinite and metaperidotite (Chl-

543 harzburgite) against the water content (measured for $\mathrm{CdA}$, this work and $\mathrm{ref}^{36}$ ) or loss of ignition

544 (L.O.I.) as a proxy for water content for samples from the literature (see Methods). The observed

545 decrease in magnetite content relative to common magnetite-bearing serpentinite is reproduced by

546 deserpentinisation infiltrated with highly reducing fluids equilibrated with graphite-bearing

547 metapelite. The decrease in magnetite for the intrinsic deserpentinisation model is coeval with the

548 precipitation of hematite (dashed red line) which is not observed in natural samples.

549

\begin{tabular}{|ll|}
\hline Serpentinites & Metaperidotite \\
$\bigcirc$ High-pressure $(\mathrm{Cd} A)$ & $\bigcirc$ Metaperidotite $(\mathrm{CdA})$ \\
High-pressure Ca-poor $(\mathrm{CdA})$ & $\bigcirc$ Transitional $(\mathrm{CdA})$ \\
Worldwide & $\bigcirc$ Metaperidotite $(\mathrm{CdG})$ \\
\hline
\end{tabular}

Thermodynamic modelling

$\lessdot$ Intrinsic deserpentinisation

Graphite metapelite-infiltrated deserpentinisation

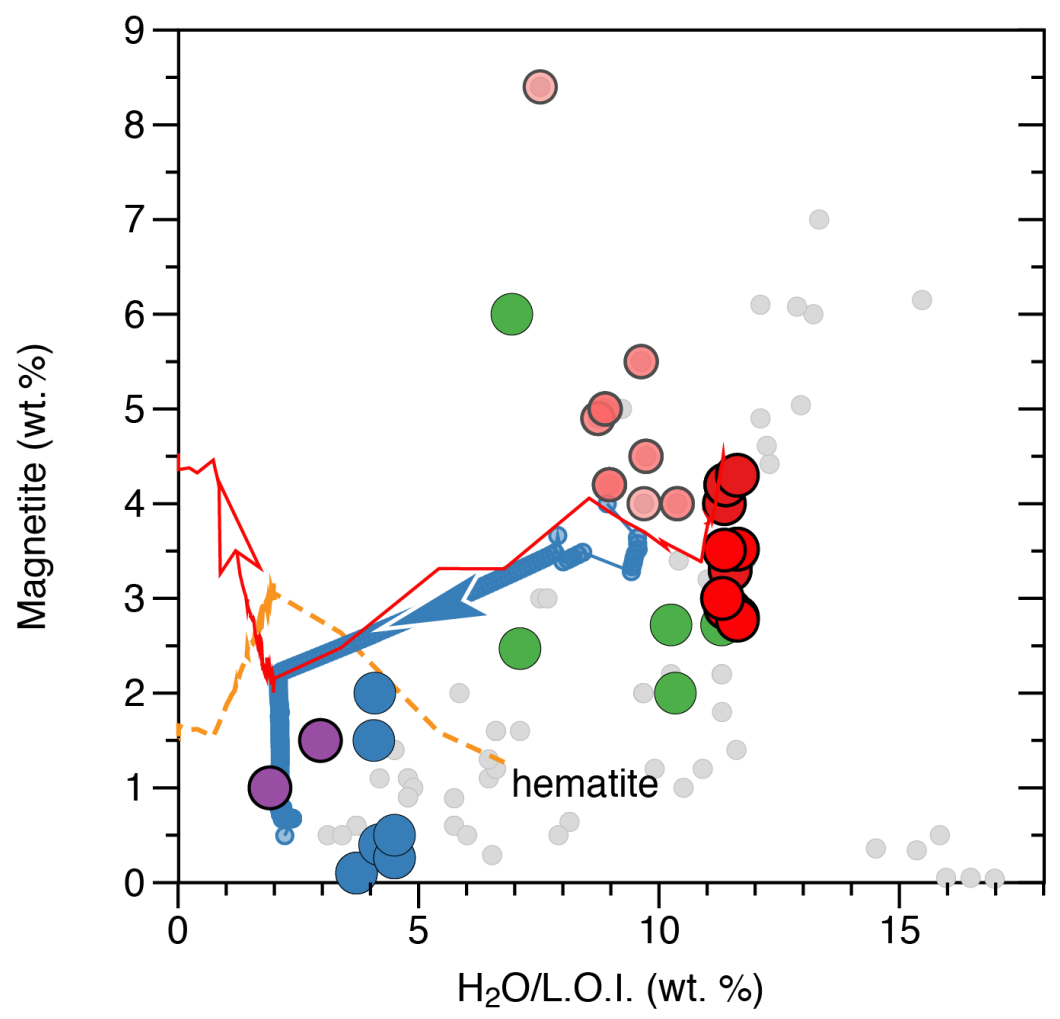


554 Figure 2. $\mathrm{X}\left(\mathrm{O}_{2}\right)-\mathrm{P} / \mathrm{T}$ (along a thermal gradient, see Methods) pseudosection ${ }^{10}$ for a representative Ca555 poor serpentinite from CdA (sample A198-05 $\mathrm{a}^{25}$ ) with sulphur and carbon content from ref ${ }^{36}$ (these

556 values were confirmed by new, duplicate analyses) and ferric iron from this work (see Supplementary

557 Table 1). The vertical line represents the intrinsic deserpentinisation for a fixed $\mathrm{O}_{2}$ content of the

558 system (Path I), corresponding to the bulk $\mathrm{O}_{2}$ for sample A198-05a (15.602 mol $/ \mathrm{kg}$ is used instead of

559 the measured $15.672 \mathrm{~mol} / \mathrm{kg}$ for better agreement with the observed sequence of mineral assemblages

560 at CdA; it likely reflects the amount of ferric iron in antigorite, not accounted for in the available solid

561 solution models ${ }^{86}$ ). The horizontal path (IIa) shows schematically the evolution if the system is

562 externally infiltrated by fluids equilibrated with metasedimentary rocks with a high reducing capacity

563 (graphite-bearing metapelite). The quantitative evolution along path IIa is shown in Figure $2 \mathrm{~b}$ in the

564 main text (see also Supplementary Figure 5 for the evolution of the speciation in the fluid). The path

565 IIb corresponds to the prograde evolution after the graphite metapelite-infiltrated deserpentinisation

566 potentially followed by CdG.

567

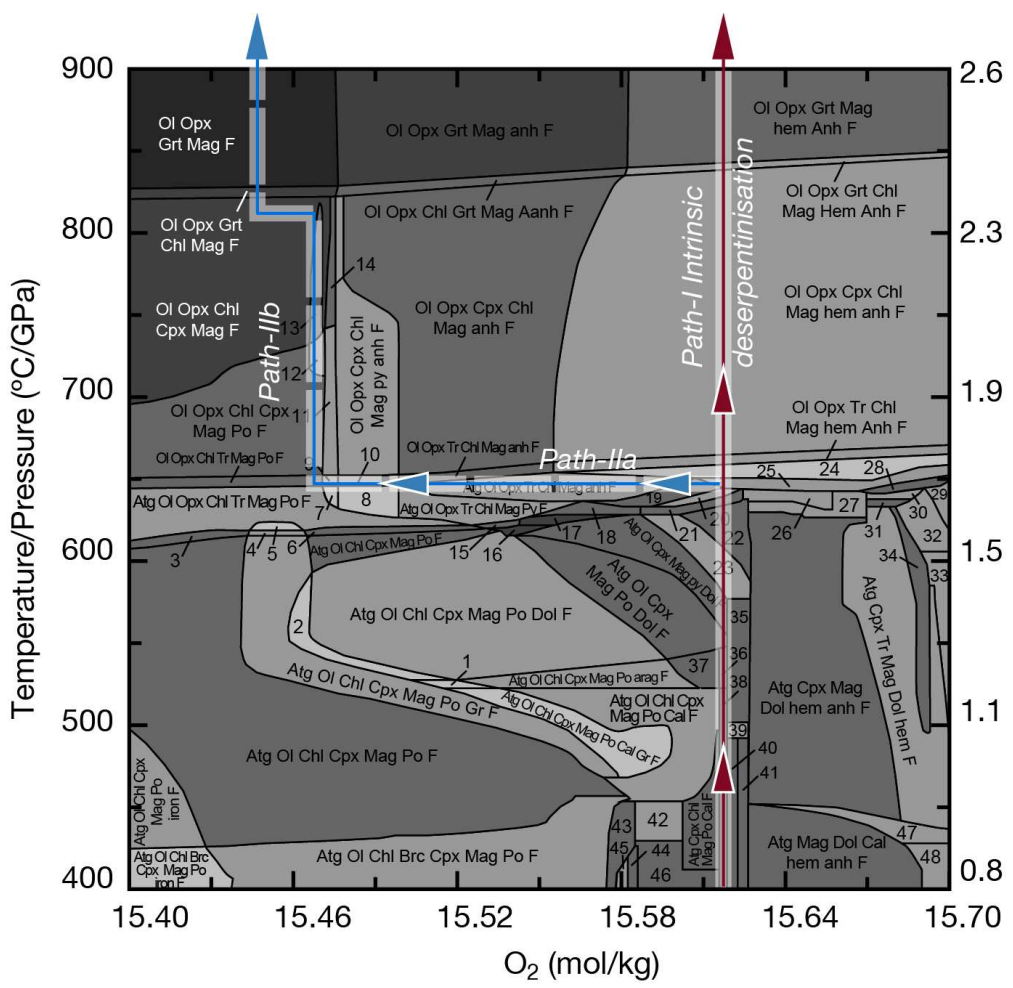

Numbered fields

1 Atg OI Chl Cpx Mag Po arag F 2 Atg OI Chl Cpx Mag Po Dol F 3 Atg OI Chl Tr Mag Po F 4 Atg Ol Chl Tr Mag Po Gr F 5 Atg Ol Opx Chl Tr Mag Po Gr F 6 Atg Ol Chl Tr Mag Po F 7 Atg Ol Opx Chl Tr Mag Po Py F 8 Atg Ol Opx Chl Tr Mag Py Anh 9 Ol Opx Chl Tr Mag Po Py F

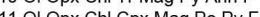
11 Opx Chi Cpx Mag Po Py F 12 Ol Opx Chl Cpx Mag Po Gr F 14 Ol Opx Chl Cpx Mag Gr 15 Atg OI Tr Chl Mag Py F 16 Atg OI CPx Mag Py F 17 Atg OI Tr Mag Py F

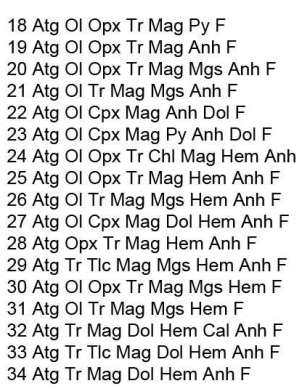

18 Atg OI Opx Tr Mag Py F 19 Atg Ol Opx Tr Mag Anh F 20 Atg OI Opx Tr Mag Mgs Anh F 21 Atg OI Tr Mag Mgs Anh F 22 Atg OI Cpx Mag Anh Dol F 23 Atg Ol Cpx Mag Py Anh Dol F 24 Atg Ol Opx Tr Chl Mag Hem Anh 25 Atg Ol Opx Tr Mag Hem Anh F 26 Atg Ol Tr Mag Mgs Hem Anh F 27 Atg Ol Cpx Mag Dol Hem Anh 28 Atg Opx Tr Mag Hem Anh F 29 Atg Tr Tlc Mag Mgs Hem Anh F 30 Atg Ol Opx Tr Mag Mgs Hem 31 Atg OI Tr Mag Mgs Hem F 32 Atg Tr Mag Dol Hem Cal Anh
33 Atg Tr Tlc Mag Dol Hem Anh 34 Atg Tr Mag Dol Hem Anh F

35 Atg Cpx Mag Py Dol Anh F 36 Atg Cpx Mag Po Py arag F 37 Atg Ol Cpx Mag Po arag F 8 Atg Cpx Mag Po Py Cal F 39 Atg Cpx Mag Py Dol Cal Anh F 40 Atg Cpx Mag Py Cal Anh F 41 Atg Mag Py Dol Cal Anh F 2 Atg Chl Brc Cpx Mag Po Cal 43 Atg Chl Brc Cpx Mag Po 45 Atg Chl Brc Cpx Mag Po Gr F 46 Atg Chl Mag Po Mo $F$ 47 Atg Cpx Mag Ca $F$ 48 Atg $\mathrm{Tr}$ Mag Dol Cal Hom Anh 
569 Figure 3. Absolute concentration of oxygen-sensitive components in the solids (expressed as $\mathrm{mol} / \mathrm{kg}$ 570 of rock A198-05a) for the pseudosection shown in Supplementary Figure 2 (see also Figure 2 in the

571 main text for the contouring of oxygen fugacity relative to the buffer FMQ). All panels were

572 computed from the absolute amounts of mineral phases containing oxygen-sensitive components and

573 their concentration in pure and solid solution endmembers from WERAMI outputs. Computations

574 used the back-calculated method for fluid speciation in PerpleX, except for pannel $\mathrm{S}^{6+}$ that was

575 computed using the lagged speciation method that allows mass balance constrains in the region below

576 the complete serpentinite dehydration. The last panel shows the redox budget referred to the whole

577 mantle reference redox state (Methods).

578

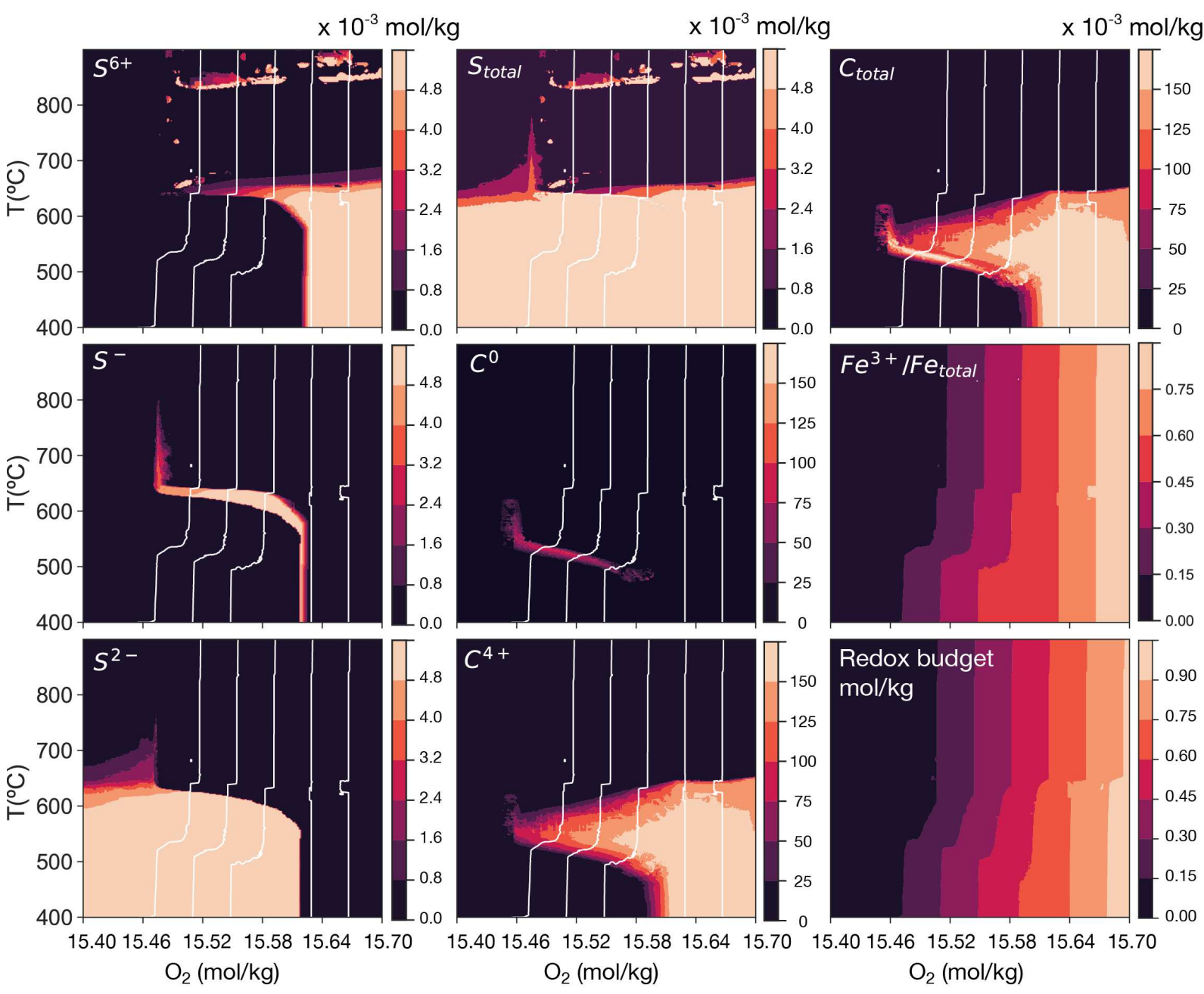

$\mathrm{O}_{2}(\mathrm{~mol} / \mathrm{kg})$ 
Figure 4. Evolution of key parameters along intrinsic deserpentinisation (intrinsic path I in Figure 2,

583 red vertical line). (a) $\mathrm{X}_{\mathrm{Mg}}$ in antigorite and their dehydrated product olivine and orthopyroxene; (b)

$584 \mathrm{H}_{2} \mathrm{O}$ content hosted in the solid phases; (c) and (d) bulk sulphur and carbon contents retained in the

585 solid phases; (e) evolution of the oxygen fugacity relative to the FMQ buffer. The blue region

586 corresponds to the temperature conditions of dehydration in Cerro del Almirez (CdA). Note that none

587 of the observables ( $\mathrm{X}_{\mathrm{Mg}}, \mathrm{S}$ and $\mathrm{C}$ content, see Fig. $2 \mathrm{~b}$ in the main text) agrees with the model predictions along with the intrinsic deserpentinisation model.

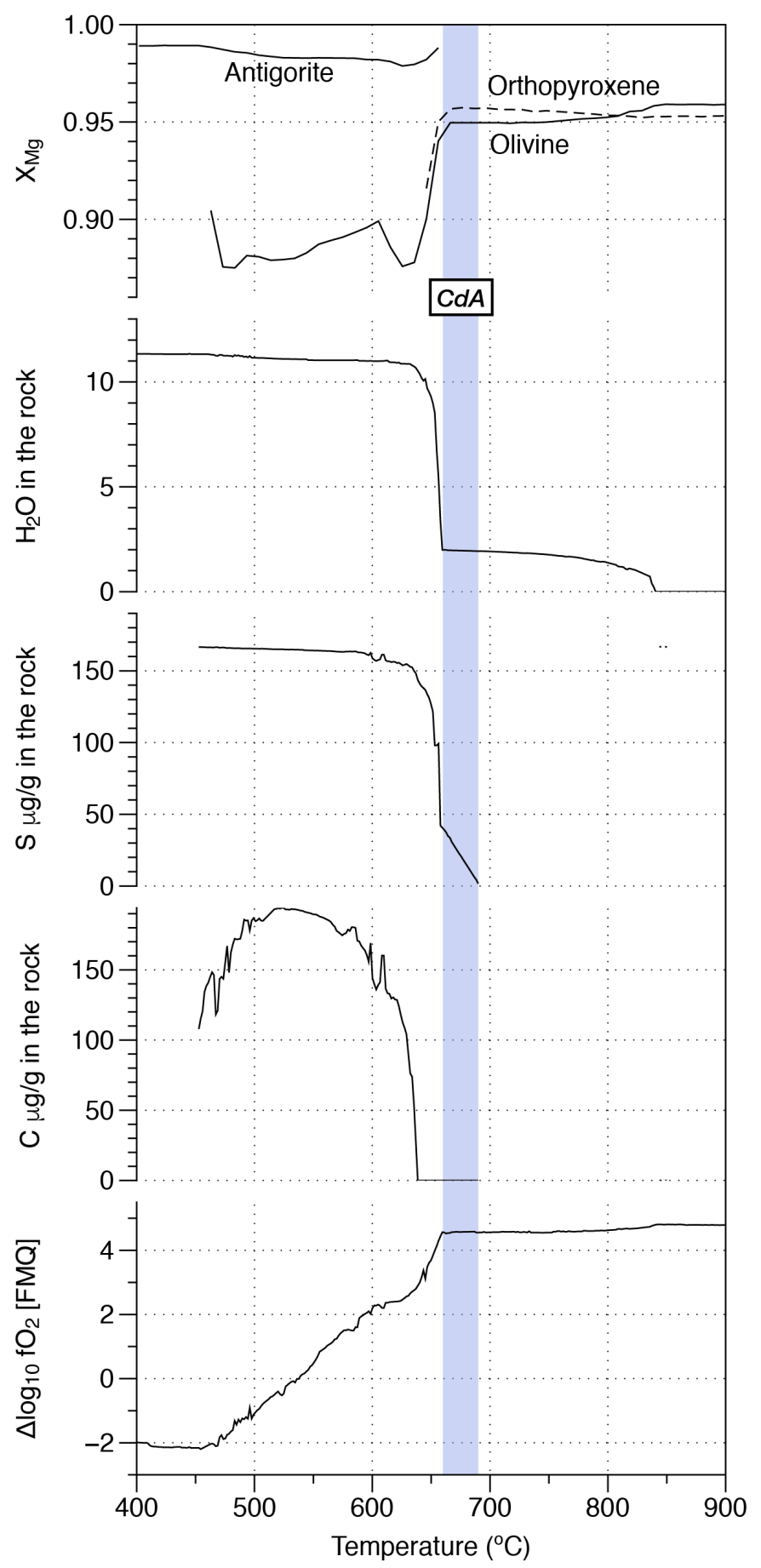


591 Figure 5. a. Fluid speciation evolution during the infiltration of a partially dehydrated

592 serpentinite with a fluid equilibrated with a graphite-bearing metapelite at $650{ }^{\circ} \mathrm{C}$ and 1.7

$593 \mathrm{GPa}$. The solvent species $\mathrm{H}_{2} \mathrm{~S}$ and $\mathrm{CO}_{2}$ are expressed as mole fraction, whereas the solute

594 species are expressed as molality $(\mathrm{mol} / \mathrm{kg})$. The main oxidising species $\left(\mathrm{HSO}_{4}^{-}\right)$is

595 represented on a linear scale whereas other less abundant species are on a logarithmic scale.

596 b. Modal (vol.\%) pyrite abundance in the metaperidotite induced by graphite metapelite fluid 597 infiltration.
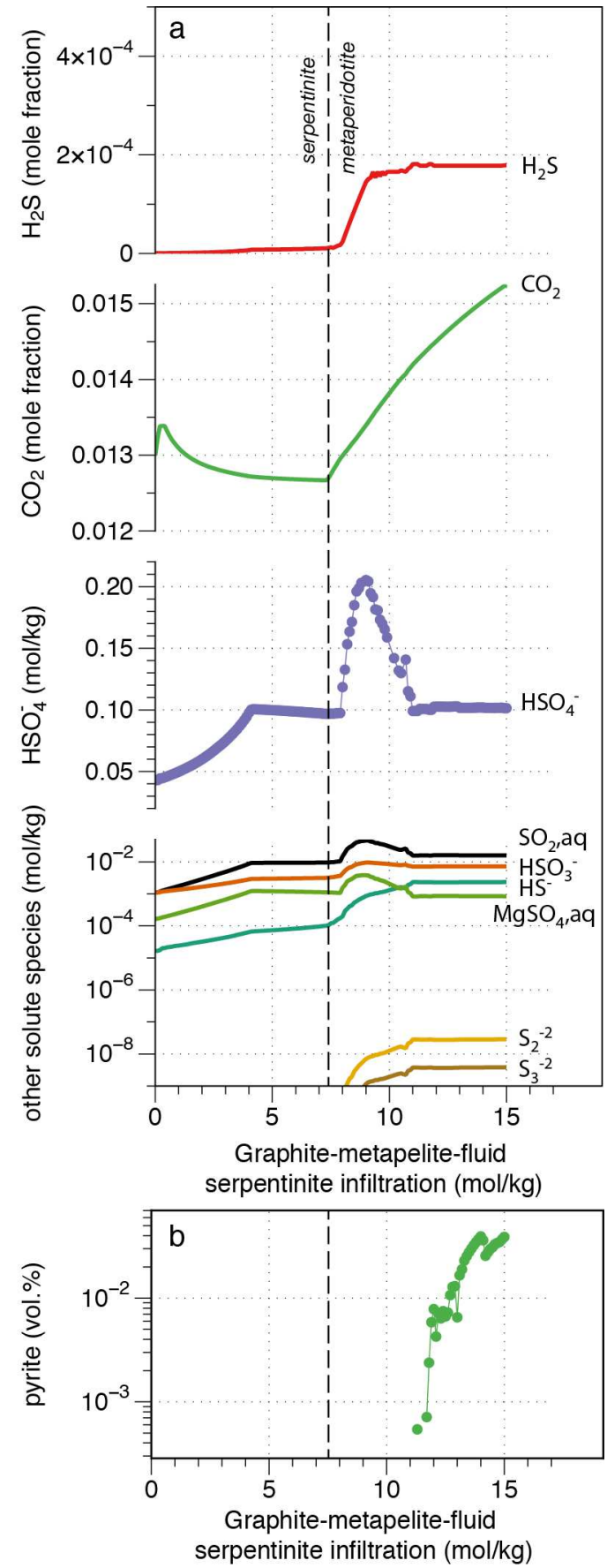
600 Figure 6. Intrinsic deserpentinization oxygen fugacity conditions (a) relative to the FMQ

601 buffer, $\Delta \log _{10} f \mathrm{O}_{2}[\mathrm{FMQ}]$ and in absolute values (b) for a representative metaserpentinite

602 (sample A198-05a, see Supplementary, Table 1) in a pressure-temperature space. Yellow dots

603 are pressure-temperature deserpentinisation conditions at the slab surface for a worldwide

604 compilation of subduction zones ${ }^{81,82}$, geographically located in (c), (d) Difference between the slab

605 surface intrinsic deserpentinisation and the mantle wedge oxygen fugacity (expressed as

$\left.606 \Delta \log _{10} f \mathrm{O}_{2}[\mathrm{FMQ}]\right)$ along the $1000^{\circ} \mathrm{C}$ isotherm.

607

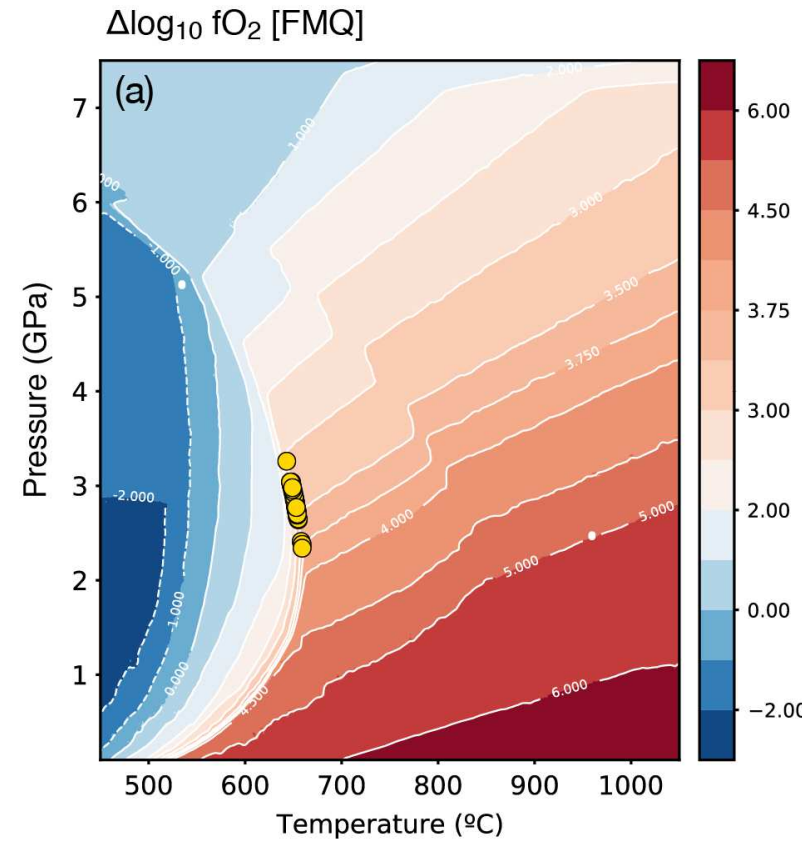

$\log _{10} \mathrm{fO}_{2}$

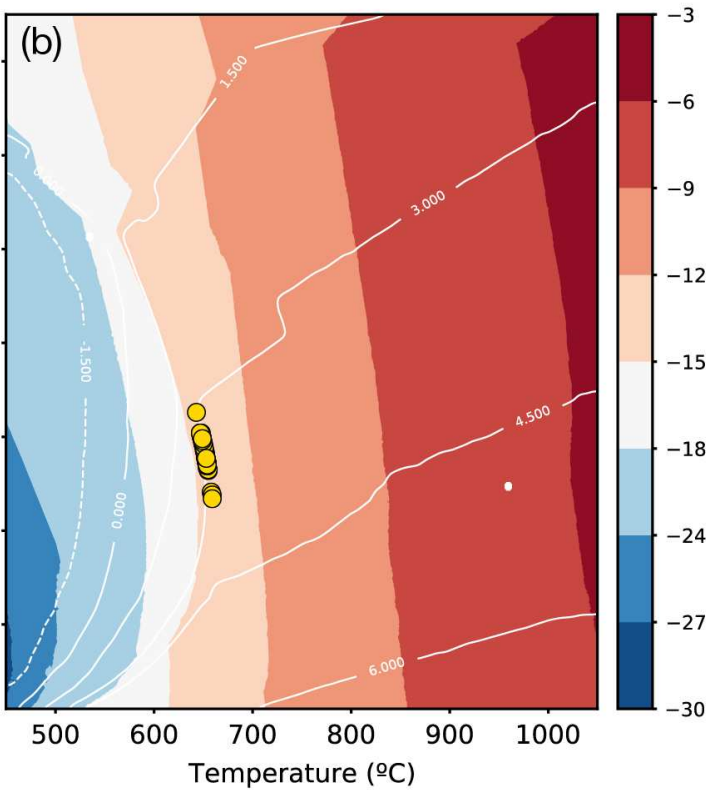

(c) Intrinsic deserpentinisation at the slab interface

(d)
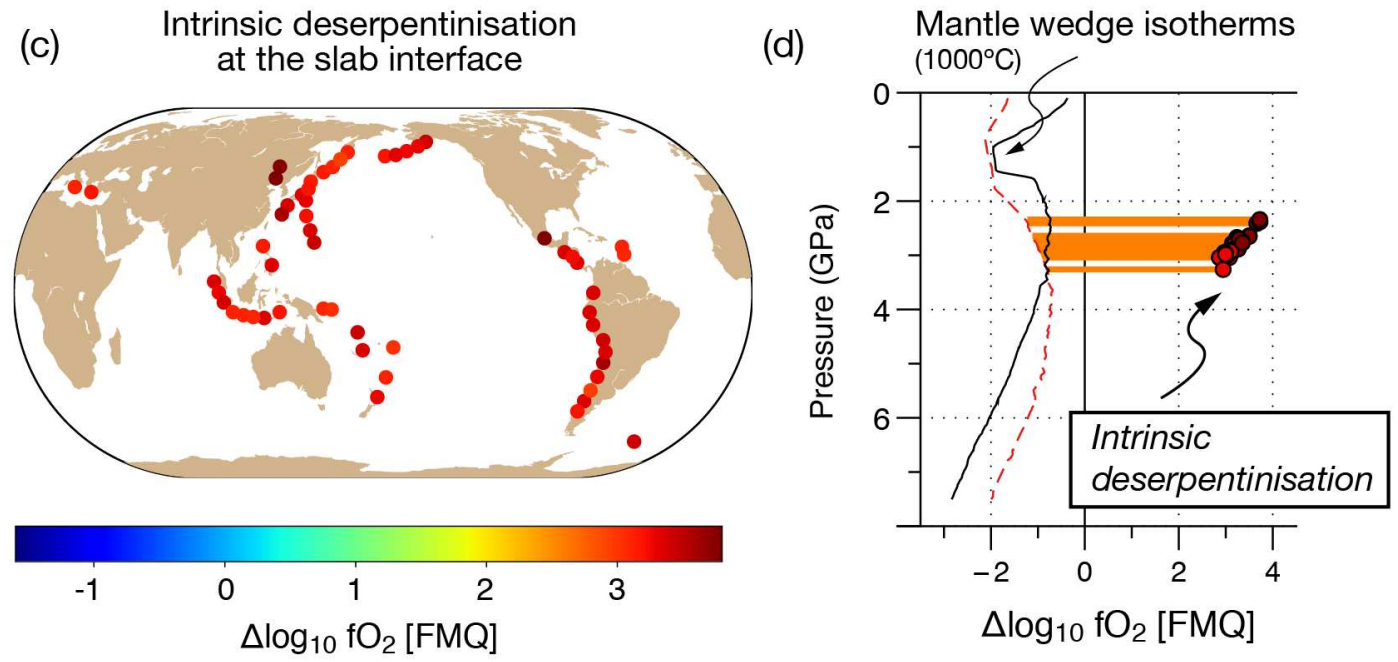
611 Figure 7. Effect of peridotite mantle wedge depletion on the $\Delta \log _{10} f \mathrm{O}_{2}$ [FMQ] evolution during

612 fluxing by different types of deserpentinisation slab fluids. The left panel shows the results

613 for (a) a depleted MORB mantle wedge source ${ }^{83}$ (DMM) and (b) an ultradepleted mantle

614 wedge source ${ }^{84}$, both for a hot (Central Cascadia) and a cold (Tonga) subduction zone. The

615 mantle wedge $\Delta \log _{10} f \mathrm{O}_{2}$ [FMQ] evolution of the mantle wedge fluxed by fluids sourced from

616 intrinsic deserpentinisation and sediment-infiltrated deserpentinisation fluids produced by the

617 infiltration of $12 \mathrm{~mol} / \mathrm{kg}$ of fluids equilibrated with GLOSS and graphite-bearing metapelite.

618 Right panels are the contours of the initial $\Delta \log _{10} f \mathrm{O}_{2}[\mathrm{FMQ}]$ of the mantle wedge for a DMM

619 (upper panel) and ultradepleted source (lower panel) before fluxing with slab fluids; shown as

620 yellow dots are the initial $\Delta \log _{10} f \mathrm{O}_{2}[\mathrm{FMQ}]$ conditions at the $1000{ }^{\circ} \mathrm{C}$ of the mantle wedge for a

621 worldwide compilation of dehydration conditions in hot to cold subduction zones. Central

622 Cascadia (hot subduction) and Tonga (cold subduction) correspond, respectively, to a

623 minimum $(2.4 \mathrm{GPa})$ and maximum pressure $(3.3 \mathrm{GPa})$ for the dehydration of serpentinisation

624 at the slab surface. Note that the initial $\Delta \log _{10} f \mathrm{O}_{2}[\mathrm{FMQ}]$ conditions depend on the thermal

625 regime of the subduction zone and the depletion of the mantle wedge source, but have a

626 subsidiary effect on the $\Delta \log _{10} f \mathrm{O}_{2}[\mathrm{FMQ}]$ evolution of the mantle wedge during fluxing of

627 different types of deserpentinisation fluids.

(a) Depleted MORB Mantle (DMM)

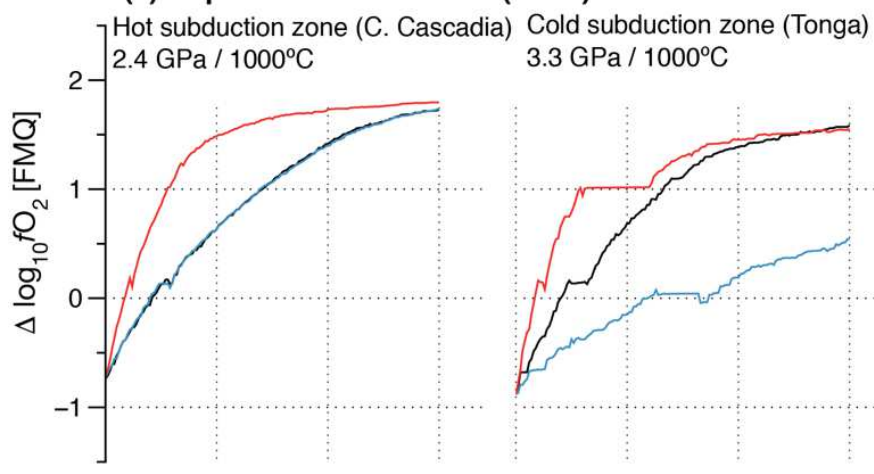

(b) Ultradepleted Mantle

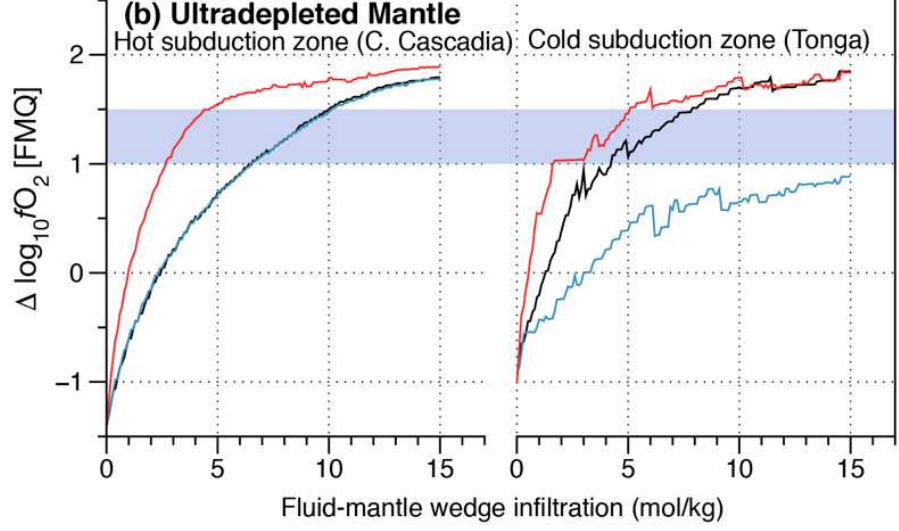

- Intrinsic deserpentinisation

- Graphite metapelite-infiltrated deserpentinisation

628

\section{Depleted MORB Mantle (DMM)}

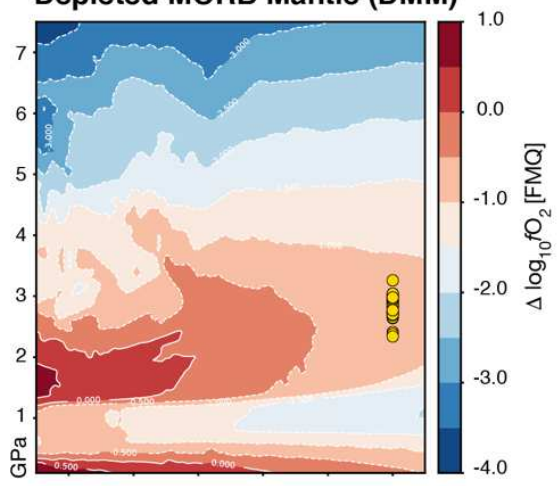

Ultradepleted Mantle

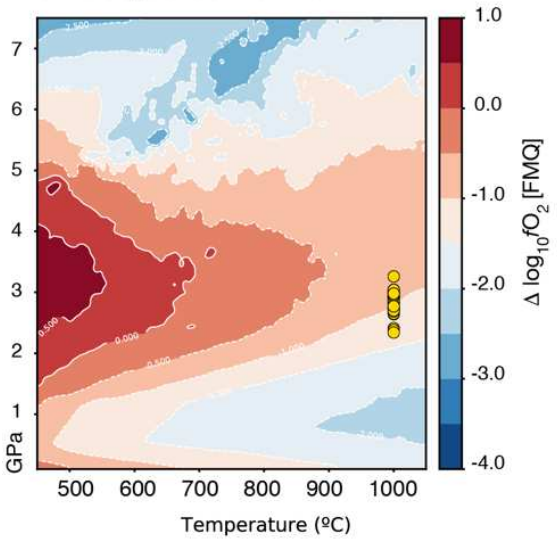


Figure 8. (a) Evolution of the $\Delta \log _{10} f \mathrm{O}_{2}[\mathrm{FMQ}]$ and the concentration of $\mathrm{HSO}_{4}{ }^{-}$-relative to

630 the intrinsic deserpentinisation fluid (ID) — during infiltration of fluids equilibrated with

631 metasedimentary rocks with a high reducing capacity (graphite-bearing metapelite) for a

632 worldwide compilation of subduction zones ${ }^{81,82}$ (colour-coded for the pressure at which the

633 serpentinite dehydrates at the slab surface, Source Data). (b) The capacity of these modified,

634 serpentinite-derived fluids (empty dots in a) to oxidise the mantle wedge on top of the slab at

635 near wet-solidus conditions is computed for the hottest (Central Cascadia) and coldest

636 (Tonga) subduction zones. A minimum value range of $\Delta \log _{10} f \mathrm{O}_{2}[\mathrm{FMQ}]$ inferred for oxidised

637 IAB source and recorded by high-pressure metasomatized mantle atop of the slab ${ }^{52,8752,87}$ is

638 given as a horizontal blue-shaded range. Sediment (graphite-bearing)-serpentinite derived

639 fluids have a variable capacity to oxidise the mantle wedge for hot and cold subduction

640 zones, a variable potential that is directly related to the contrasting solubility of $\mathrm{HSO}_{4}$ - for the

641 two extreme thermal cases. The metasomatized mantle wedge has an initially depleted

642 composition ${ }^{83}$. Squares and stars on the red and blue lines indicate the condition range limits

643 at which pyrrhotite (Po), or anhydrite (anh) are the stable minerals hosting $\mathrm{S}$ in the rocks. For

644 an ultradepleted MORB mantle, see Supplementary, Fig. 7. For interaction with sediments

645 with low reducing capacity (GLOSS), see Fig. 3 in the main text.

646

(a) Slab interface

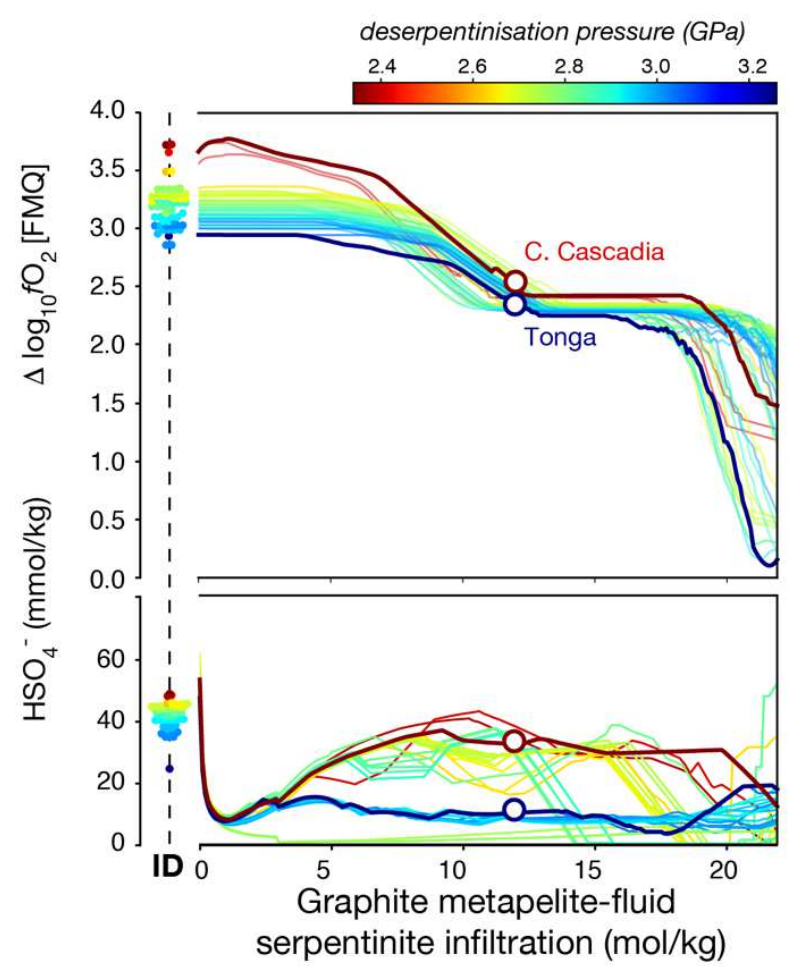

(b) Mantle Wedge
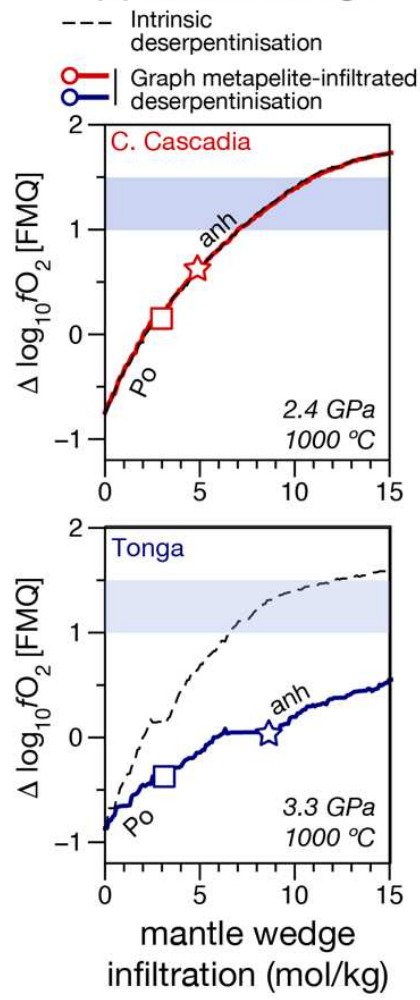


\section{Supplementary Tables}

650 Supplementary Table 1. Bulk rock compositions used for thermodynamic modelling.

651 Supplementary Table 2. Fluid composition and speciation for CdA peak metamorphic

652 conditions at intrinsic dehydration and after interaction ( $12 \mathrm{~mol} / \mathrm{kg})$ with sediment with high

653 reducing capacity

654

655 Source data

656 Supplementary file (csv). Worldwide subduction zone database ${ }^{81}$ used to compute the

657 pressure and temperature conditions for the slab surface deserpentinisation ${ }^{82}$. These pressure

658 and temperature conditions are used to compute the intrinsic fluid chemistry and the fluid

659 composition for high and low-reducing capacity sediments (graphite and GLOSS

660 respectively) that are used for infiltration at the same serpentinite dehydration pressure and

661 temperature conditions. Main species are given for the three cases: intrinsic ( intr) and for

662 infiltration of $12 \mathrm{~mol} / \mathrm{kg}$ for the cases of graphite-bearing and GLOSS sediments derived

663 fluids (_graph and_gloss). Fluid bulk compositions are given in mol per formula unit of fluid

664 and species concentrations are given in $\mathrm{mol} / \mathrm{kg}$. This database can be generated for other

665 degrees of infiltration using a Jupyter notebook available upon request. 


\section{Supplementary Files}

This is a list of supplementary files associated with this preprint. Click to download.

- ExtendedDataTable2.pdf

- ExtendedDataTable1.pdf

- ExtendedDataFigure1.pdf

- ExtendedDataFigure2.pdf

- ExtendedDataFigure3.pdf

- ExtendedDataFigure4.pdf

- ExtendedDataFigure5.pdf

- ExtendedDataFigure6.pdf

- ExtendedDataFigure7.pdf

- ExtendedDataFigure8.pdf 